\title{
Evolution of Aflatoxins Levels during Storage of Cowpeas (Vigna unguiculata L Walp) Bagged Pics Containing Lippia multiflora Moldenke Leaves and Ivorian Exposure Risk
}

\author{
KONAN K. Constant ${ }^{1}$, COULIBALY Adama ${ }^{1}$, SIDIBE Daouda ${ }^{1}$, CHATIGRE Olivier ${ }^{1}$, \\ BIEGO Godi Henri Marius ${ }^{1,2}$ \\ ${ }^{1}$ Laboratory of Biochemistry and Food Science, Training and Research Unit of Biosciences, Felix HOUPHOUET-BOIGNY University of \\ Abidjan, 22 BP 582 Abidjan 22, Cote d"Ivoire \\ ${ }^{1}$ Laboratory of Biochemistry and Food Science, Training and Research Unit of Biosciences, Felix HOUPHOUET-BOIGNY University of \\ Abidjan, 22 BP 582 Abidjan 22, Cote d"e Ivoire \\ ${ }^{1}$ Laboratory of Biochemistry and Food Science, Training and Research Unit of Biosciences, Felix HOUPHOUET-BOIGNY University of \\ Abidjan, 22 BP 582 Abidjan 22, Cote d'Ivoire \\ ${ }^{1}$ Laboratory of Biochemistry and Food Science, Training and Research Unit of Biosciences, Felix HOUPHOUET-BOIGNY University of \\ Abidjan, 22 BP 582 Abidjan 22, Cote d"eIvoire \\ ${ }^{1}$ Laboratory of Biochemistry and Food Science, Training and Research Unit of Biosciences, Felix HOUPHOUET-BOIGNY University of \\ Abidjan, 22 BP 582 Abidjan 22, Cote d'Ivoire \\ ${ }^{2}$ Department of Public Health, Hydrology and Toxicology, Training and Research Unit of Pharmacological and Biological Sciences, Felix \\ HOUPHOUET-BOIGNY University, BP 34 Abidjan, Cote d"Ivoire

\begin{abstract}
The methods of cowpea storage using biopesticides, without risk to human health and the environment, could be an anti-pest infestations on stocks of cereals and legumes. Thus, the evolution of aflatoxins (B1, B2, G1 and G2) during the storage of cowpea (Vigna unguiculata L Walp) in PICS bags containing a biopesticide was studied. The risk of exposure associated with the consumption of cowpea was also studied. The results show the presence of total aflatoxins in $29.41 \%$ of the samples, with $8.82 \%$ of aflatoxin B1 at levels above the reference values. PICS bags ensure a longer shelf as control polypropylene bags. Adding Lipppia multiflora makes this even more effective conservation and allows the preservation of the health quality of cowpea to 8 months. The risk of aflatoxin exposure is lower when cowpeas stored in PICS bags with biopesticide that when stored in PICS bags without biopesticide or polypropylene bags.
\end{abstract} \\ alternative in the fight against pests. The leaves of savanna tea (Lippia multiflora Moldenke) were tested for their antifungal properties,
}

Keywords: Cowpea, aflatoxins daily intake, PICS bags, storage with biopesticides

\section{Introduction}

Cowpea (Vigna unguiculata L. Walp.) is a legume of hot areas of African origin and cultivated for human food and livestock needs. In 2008, global production of cowpea amounted to over 5.7 million tons of dry seeds on 7.5 million ha, of which $70 \%$ were produced in Africa [1]. The big problem of the cowpea sector remains one of the storage. The storage is an important step in safeguarding food security [2]. The resolution of cowpea storage problem will have a positive impact on production in Cote d'Tvoire, which is still marginal [3]. Cowpea is thus subjected to fungal, bacteria, viruses and pests attack [4].

Post-harvest losses are estimated at more than $30 \%$ of production. These losses are mainly due to insects (44\%), rodents $(30 \%)$, molds and other $(26 \%)$ [5], [6]. The pest activity creates an environment for mold growth of Aspergillus, Penicillium and Fusarium responsible for the deterioration of market quality, nutritious quality and above all health quality cereals and legumes stocks [7]-[11]. Mold, in addition to altering the appearance, smell and taste of grain, also produce mycotoxins such as aflatoxins B1, B2, $\mathrm{G} 1$ and $\mathrm{G} 2$ and others that are harmful to the health of animals and the man [7], [12], [13].

Aflatoxins B1, B2, G1 and G2 are mycotoxins produced by molds of the genus Aspergillus [14] The fear Caused by aflatoxins thesis is from the threat posed to humans They and animals. Indeed, the primary target organ for aflatoxins is the liver [15] They can also disrupt the immune system, causes growth retardation and Possibly death in humans and pets [16]-[19]. Aflatoxin B1 is teratogenic, immunosuppressive and could affect reproductive functions [20]. It was also proved that aflatoxins significantly slow the recovery of child victims of protein-calorie malnutrition [21]. Furthermore, exposure to high water equivalent of aflatoxin, at weaning, can affect the growth of children as Some authors-have pointed to Benin and Togo [22], [23]. 


\section{International Journal of Science and Research (IJSR) \\ ISSN (Online): 2319-7064}

Index Copernicus Value (2013): 6.14 | Impact Factor (2015): 6.391

The presence of aflatoxins alters the health quality of contaminated food (nuts, corn, peanuts, oil seeds, spices, dried fruits, cocoa products) [24]. In 2004, aflatoxins-havebeen responsible for the Deaths of 80 people in Kenya Following The consumption of corn flour Heavily contaminated aflatoxin [25]. Aflatoxin B and G are mainly found in the cake and a minority in the crude oil [20].

Also maintaining an ambient humidity levels below the range of mold development is essential to preserve cowpea fungal colonization. In attics or stores, cowpea strikes a balance with the ambient relative humidity. General manner, moisture is the presence of water or water vapor in air or in a substance. It is one of the parameters that drive growth, mold growth and toxinogenesis. Thus, the fungal development not only depends on ambient humidity, but also the water activity of the substrate [26].

The methods used to reduce or eliminate these problems of conservation of cereals and legumes, are generally chemical insecticides that can cause poisoning of consumers, resistance in pests and have a negative impact on the environment [27], Hence the importance of using natural alternatives. Moreover, the restriction imposed by the food industry and regulatory organizations on the use of certain synthetic additives products have led to a renewed interest in the search for alternatives such as biopesticides, especially those of plant origin [28], [29]. The use of aromatic plants, such as insecticides or antimicrobial agents has several advantages. These plants are natural, which means more safety for the population and the environment. They are also considered at low risk for development of resistance by insects and pathogenic microorganisms [27], [30]. Thus, the aim of this study is to monitor some health parameters (aflatoxins B1, B2, G1, G2, total aflatoxins), moisture and water activity of cowpea in storage in triple bags pouch applications using a biopesticide.

\section{Material and Methods}

\subsection{Experimental site}

The experiment was performed at Laboratory of Biochemistry and Food Sciences (LABSA) UFR Biosciences at the University Félix HOUPHOUET-BOIGNY. The different bags were kept in a laboratory storeroom to $27.78 \pm$ $0,19^{\circ} \mathrm{C}$ temperature and $75.0 \pm 0.99 \%$ relative humidity. Wooden pallets were arranged floored as support for PICS bags.

\subsection{Collection of cowpea used in the study}

Cowpea grains used belong to the local variety "Vya". They were collected from producers of the Loh-Djiboua region (5 $\circ 50$ 'North $5^{\circ} 22^{\prime}$ West) from April to May 2015, just after harvest. After the shelling, the grains have not undergone any treatment were sent to the laboratory for packaging.

\subsection{Collection and processing of biopesticides}

The Laboratory of Biochemistry and Food Science has a scope on the conservation of cereals, pulses and other agricultural products for many years. Biopesticides are a good alternative in the fight against pests and fungus. Thus, Lippia multiflora was used in this study for these phytosanitary properties. It is perennial and fragrant shrubs spontaneously encountered in areas of central and northern Côte d'Ivoire (Tia, 2012; Ekissi et al, 2014). [31] [32]. The leaves of L. multiflora were harvested and dried in the sunlight for a week in GBEKE region in May 2015. The dried leaves were chopped into fine particles before use.

\subsection{Using the triple bagging}

Storage bags used in our study, were made of polypropylene bags and polyethylene bags (Purdue Improved Cowpea Storage: PICS) developed by Purdue University for storing cowpeas from Niger. These bags, obtained from suppliers, are composed of a triple bagging system.

\subsection{Storage method for cowpea grains}

Storage of cowpea grains was conducted from June 2015 to February 2016, according to a central composite design with 5 levels and 2 variables. The latter has set up 6 lots $(1$ control polypropylene bag, 1 control PICS bag, and 4 lots in PICS bags containing different proportions of biopesticides $(0.7 \%$, $2.5 \%, 4.3 \%$ and $5 \%$ of the mass of bag per sheet). the filling of the bags of $50 \mathrm{~kg}$ was made in stratum, alternating cowpea seeds and leaves of biopesticides.

\subsubsection{Sampling}

The sampling was performed at the beginning of the storage (0 month), then $1 ; 2 ; 4,5 ; 7$ and 8 months later, in triplicate. Thus, $1 \mathrm{~kg}$ of cowpea samples from each PICS bag was gathered through the top, the centre and the bottom opening sides. Cowpea samples were aflatoxins (B1, B2, G1 and G2) and physicochemical properties measurements were achieved.

\subsubsection{Determination of moisture content}

The moisture content was valued according to the method described by AOAC (2000) [33]. A cowpea sample of $5 \mathrm{~g}$ was dried at $105^{\circ} \mathrm{C}$ into an oven till constant weight. The result was expressed from the equation below:

Moisture content $(\%)=\mathbf{1 0 0}-(\mathrm{Wl} \times 100 / W s)$

With Wl, weight lost from samples after drying; Ws, weight of raw samples.

\subsubsection{Determination of water activity}

The water activity was measured with a HygroLab Rotronic hygrometer according to indications of McCormick (1995) [34]. Prior to assays, the hygrometer was calibrated with specific water activity salts. Then, samples of $5 \mathrm{~g}$ of ground cowpea were put into standard dry empty containers for the Aw analysis. The water activity digital measures were directly displayed by the hygrometer. 


\section{International Journal of Science and Research (IJSR) \\ ISSN (Online): 2319-7064}

Index Copernicus Value (2013): 6.14 | Impact Factor (2015): 6.391

\subsubsection{Aflatoxins analysis}

\subsubsection{Extraction and purification of aflatoxins}

Chemical reagents (acetonitrile, methanol and chloroform) and standard aflatoxins (AFB1, AFB2, AFG1 and AFG2) were used for the study. Reagents were purchased from Carlo Erba (Spain) with analytical grade, while standard aflatoxins were provided from Sigma (Sigma, St Louis, MO, USA). Biological aflatoxins (B1, B2, G1 and G2) were extracted and purified from cowpea using the official guidelines of AOAC [35]. To $25 \mathrm{~g}$ of ground cowpea put in an erlenmeyer flask, $100 \mathrm{~mL}$ of $80 \%$ methanol aqueous solution were added. The mixture was homogenized, put in darkness at room temperature for $12 \mathrm{~h}$, and then filtered with a Whatman paper (Wathman $\mathrm{N}^{\circ} 4$ ). Thereafter, $50 \mathrm{~mL}$ of the filtrate were added with $40 \mathrm{~mL}$ of a mixture deriving from phosphotungstic acid-zinc sulfate-water $(5 / 15 / 980, \mathrm{w} / \mathrm{w} / \mathrm{v})$, and kept at ambient temperature for $15 \mathrm{~min}$ before filtration upon Whatman paper. Aflatoxins were extracted from the outcoming filtrate with 3 volumes of $10 \mathrm{~mL}$ of chloroform. The extracts were collected into a $50 \mathrm{~mL}$ flask and processed with rotative evaporator (Buchi Rotavapor R-215) at $40^{\circ} \mathrm{C}$ for evaporation of the chloroform reagent. Finally, $0.4 \mathrm{~mL}$ of hydrochloric acid and $4.6 \mathrm{~mL}$ of bidistillated water were added to the dry extract, and the solution was filtered through filter Rezist in a chromatographic tube then passed through an immunoaffinity column (column RiDA aflatoxin, Biopharm, Germany).

\subsubsection{Quantification of Aflatoxins}

Determination of aflatoxins contents was achieved with high performance liquid chromatography column, using a Shimadzu liquid chromatograph (Kyoto, Japan) fitted with fluorescence detector ( $\chi$ exc $365 \mathrm{~nm}$; $\chi \mathrm{em} 435 \mathrm{~nm}$ ) and Shimpack column and pre-column (Shim-pack GVP-ODS: 250 $\mathrm{mm} \times 4,6 \mathrm{~mm}, 10$ x 4,6 mm, respectively). Twenty (20) $\mu \mathrm{L}$ of the filtrate were injected on the column. Components were eluted with a mobile phase prepared with methanol/ water/ acetonitrile (60:20:20, v/v/v) and using a gradient programme of $1 \mathrm{~mL} / \mathrm{min}$. Assays were performed in triplicate. Validation parameters of the aflatoxins contents analysis, especially Limits of Detection (LOD), Limits of Quantification (LOQ), repeatability and reproducibility traits and percentage of extractions, were valued. Thereafter, the contents of aflatoxins B1, B2, G1 and G2 were estimated, and then the total aflatoxins content was calculated from the sum of the overall aflatoxins. The table I presents the HPLC analysis conditions and the results of method validation

\subsubsection{Assessment of total aflatoxins and aflatoxin B1 exposures from cowpea daily intake for the adult Ivorian}

The mean aflatoxins level in cowpea stored for 0 and 8 months, and the mean cowpea consumption and body weight from Ivorian adult, allowed estimation of the daily exposures to total aflatoxins and aflatoxin B1 [36], [37]. According to. Langyintuo et al (2003) [38], the daily consumption of cowpea in Côte d'Tvoire is 4,93 g per capita/day. The aflatoxin exposure or intake was calculated using the formula of the following equation:

$$
\mathbf{E A I}=(\mathbf{T} \times \mathbf{Q}) / \mathbf{B w}
$$

With EAI, the Estimated Aflatoxins exposure from cowpea daily Intake (ng/kg of Bw/day); $\mathrm{T}$, the aflatoxins contents in cowpea stored (ng/kg); Q, the daily Intake of cowpea (g/day); $\mathrm{Bw}$, the Body weight of an adult person $(70 \mathrm{~kg})$.

The estimated aflatoxins exposures were also expressed in relation with the maximal mean levels of total aflatoxins and AFB1 reported by the European Union (EU Regulation No 420/2011) [39] in cowpea subjected to physical treatment before human

\subsection{Statistical analysis}

All analyses were performed in triplicate and the full data were statistically treated using SPSS software (version 20.0). It consisted in Analysis of Variance according to two factors: duration and method of storage. Means derived from parameters were compared with the Tukey High Significant Difference test at 5\% significance level. Correlations between parameters were also assessed according to the Pearson index. Then, Multivariate Analyses through Principal Components Analysis (PCA) and Ascending Hierarchical Clusters analysis (AHC) were performed using STATISTICA software (version 7.1).

\section{Results}

Statistical tests indicate a significant change $(\mathrm{P}<0.01)$ the content of the parameters evaluated according to storage time and the type of packaging, if the cowpea was in PICS bags or not and whether it was treated or not treaty with the biopesticide (Tables 2 and 3).

\subsection{Evolution of moisture during storage}

Table 2 shows the moisture content of cowpea grains stored in different PICS bags. With an average of $10.03 \pm 0.21 \%$ at baseline ( 0 months $)$, the moisture content increased significantly $(\mathrm{P}<0.001)$ during the storage period (Table 3$)$. The higher moisture values were recorded after 4.5 months of storage in the control without PICS $(14.67 \pm 0.15 \%)$ and 8 months of storage in the PICS control without biopesticide $(14.10 \pm 0.11 \%)$ (Figure 1). In PICS bags with different proportions of biopesticide, moisture contents after 8 months of storage were similar with a neighboring average of $12.0 \pm$ $0.12 \%$. Furthermore, the interaction between the type of packaging and the storage period has a significant effect on this parameter as found in Tables 2 and 3 .

\subsection{Evolution of water activity values during storage}

Table 2 shows the values of the water activity of cowpea grains stored in different PICS bags. The activity of cowpea beans water control without PICS (TSP) increases faster in 4.5 months from $0.61 \pm 0.01$ ( 0 months) to $0.96 \pm 0.01$ ( 4.5 months). This pace is followed by the PICS bag without biopesticide (H0) that in 8 months increased from $0.61 \pm$ 0.01 to $0.92 \pm 0.01$ (Figure 2). The water activity in 8 months ${ }^{\text {ee }}$ cowpea storage was $0.86 \pm 0.01$ for $\mathrm{H} 1$ and $\mathrm{H} 2$. For $\mathrm{H} 3$ and $\mathrm{H} 4$, the variation is significant, but the average value 


\section{International Journal of Science and Research (IJSR) \\ ISSN (Online): 2319-7064 \\ Index Copernicus Value (2013): 6.14 | Impact Factor (2015): 6.391}

is $0.70 \pm 0.01$. The interaction between the type of packaging and the storage time is significant with $\mathrm{P}<0,001$

\subsection{Validation parameters for Aflatoxins assessment using HPLC}

Using HPLC device, Limits Of Detection (LOD) of respective aflatoxins $\mathrm{B} 1, \mathrm{~B} 2, \mathrm{G} 1$ and $\mathrm{G} 2$ are $6.18 \mathrm{ng} / \mathrm{kg}$, $0.058 \mathrm{ng} / \mathrm{kg}, 114.5 \mathrm{ng} / \mathrm{kg}, 2.64 \mathrm{ng} / \mathrm{kg}$, while their Limits Of Quantification (LOQ) are $6.50 \mathrm{ng} / \mathrm{kg}, 0.108 \mathrm{ng} / \mathrm{kg}, 124.9$ $\mathrm{ng} / \mathrm{kg}, 2.94 \mathrm{ng} / \mathrm{kg}$. The mean recoveries fluctuate between $0.50 \%$ and $3.75 \%$ for the repeatability assays and between $0.89 \%$ and $4.93 \%$ for reproducibility assays. However, for aflatoxins B1, B2, G1 and G2, respective rates of extraction of $\quad 98.92 \pm 2.49 \%, \quad 97.53 \pm 1.93 \% \quad 95.31 \pm 0.33 \% \quad$ and $97.63 \pm 2.10 \%$ are recorded.

\subsection{Evolution of aflatoxins contents during storage}

Table 2 shows the levels of AFB1 and AFB2 of cowpea grains stored in different PICS bags. With an average of 0.16 $\pm 0.01 \mu \mathrm{g} / \mathrm{kg}$ at the start (0 month), AFB1 significantly increased $(\mathrm{P}<0.001)$ during the storage period according to the type of packaging (Table II). The highest AFB1 values were recorded after 4.5 months of storage in the control without PICS (TSP) $(9.21 \pm 0.01 \mu \mathrm{g} / \mathrm{kg})$ and 8 months of storage in the PICS control without biopesticide (H0) $(8.41 \pm 0.48 \mu \mathrm{g} / \mathrm{kg}$ ) (Figure 3 ). In PICS bags with different proportions of biospesticide, levels of AFB1 after 8 months of storage on average are $2.09 \pm 0.04 \mu \mathrm{g} / \mathrm{kg}, 1.31 \pm 0.01$ $\mu \mathrm{g} / \mathrm{kg}, 1.29 \pm 0,03 \mu \mathrm{g} / \mathrm{kg}$ and $1.14 \pm 0.01 \mu \mathrm{g} / \mathrm{kg}$ respectively for H1, H2, H3 and H4. Furthermore, the interaction between the type of packaging and the storage period has a significant effect on this parameter as found in Tables 2 and 3. The amount of aflatoxin B2 in the control without PICS (TSP) increased significantly in 4.5 months from $0.03 \pm 0.00 \mu \mathrm{g} / \mathrm{kg}$ ( 0 months) to $1.00 \pm 0.01 \mu \mathrm{g} / \mathrm{kg}$. It's the same look that is followed by AFB2 in the PICS bag without biopesticide (H0) that in 8 months increased from $0.03 \pm 0.01$ to $1.03 \pm 0.06$ $\mu \mathrm{g} / \mathrm{kg}$ (Figure 4). The amount of AFB2 in H2 in 8 months cowpea storage is lower than other PICS bags with biopesticide. It is $0.20 \pm 0.01 \mu \mathrm{g} / \mathrm{kg}$ whereas for $\mathrm{H} 1, \mathrm{H} 3$ and $\mathrm{H} 4$ in the quantities AFB2 are respectively $0.31 \pm 0.01 \mu \mathrm{g} / \mathrm{kg}$, $0.54 \pm 0.01 \mu \mathrm{g} / \mathrm{kg}$ and $0.46 \pm 0.01 \mu \mathrm{g} / \mathrm{kg}$. The interaction between the type of packaging and the storage time is significant with $\mathrm{P}<0,001$.
Table II also presents the AFG1 and AFG2 contents cowpea grains stored in different PICS bags. With an average of 1.13 $\pm 0.01 \mu \mathrm{g} / \mathrm{kg}$ at the start (0 months), AFG1 increases significantly $(\mathrm{P}<0.001)$ during the storage period and depending on the type of packaging (Tables 2 and 3). The highest values of AFG1 were recorded after 4.5 months of storage in the control without PICS (TSP) $(78.77 \pm 0.38 \mathrm{mg} /$ $\mathrm{kg}$ ) and after 8 months of storage in the PICS control without biopesticide (H0) $(61.50 \pm 2.80 \mu \mathrm{g} / \mathrm{kg})$. In PICS bags with different proportions of biopesticide, the contents of AFG1 after 8 months of storage are averaging $15.40 \pm 0.40 \mu \mathrm{g} / \mathrm{kg}$ $14.10 \pm 0.16 \mu \mathrm{g} / \mathrm{kg}, 11.10 \pm 0,07 \mu \mathrm{g} / \mathrm{kg}$ and $9.79 \pm 0.80$ $\mu \mathrm{g} / \mathrm{kg}$ respectively for $\mathrm{H} 1, \mathrm{H} 2, \mathrm{H} 3$ and $\mathrm{H} 4$ (Figure 5). Furthermore, the interaction between the type of packaging and the storage period has a significant effect on this parameter as found in Tables 2 and 3. The amount of aflatoxin G2 in the control without PICS (TSP) varying from $0.98 \pm 0.01 \mathrm{mg} / \mathrm{kg}$ to $56.90 \pm 0.47 \mathrm{mg} / \mathrm{kg}$ for the 4.5 months of storage possible. It's the same look that is followed in the PICS bag without biopesticide (H0) that in 8 months increased from $0.98 \pm 0.01 \mu \mathrm{g} / \mathrm{kg}$ to $26.77 \pm 2.11 \mu \mathrm{g} / \mathrm{kg}$ (Figure 6). The amount of AFG2 during the 8 months storage of cowpea varied depending on the duration of storage and the type of packaging in PICS bags with biopesticide $(\mathrm{P}<0,001)$ (Tables 2 and 3). But the values are well below the values of TSP and $\mathrm{H} 0$.

The total aflatoxin is the result of the sum of all aflatoxins in cowpea. That its variation is significant both with the duration of storage and packaging type. The total amount of aflatoxin in the control without PICS (TSP) varying from $2.30 \pm 0.01 \mu \mathrm{g} / \mathrm{kg}$ to $145.87 \pm 0.88 \mu \mathrm{g} / \mathrm{kg}$ for the 4.5 months of storage possible. This is roughly the same pace as in the PICS bag without biopesticide (H0) that in 8 months increased from $2.30 \pm 0.01 \mu \mathrm{g} / \mathrm{kg}$ to $97.71 \pm 0.55 \mu \mathrm{g} / \mathrm{kg}$ (Figure 7). The amount of AFT during the 8 months storage of cowpea has varied over time and the type of packaging in bags with peaks biopesticide $(\mathrm{P}<0,001)$ (Tables 2 and 3 ). But the values are well below the values of the TSP bags and H0 with respective averages of $28.92 \pm 0.43 \mu \mathrm{g} / \mathrm{kg}, 25.23 \pm 0.34$ $\mu \mathrm{g} / \mathrm{kg} 20.59 \pm 0.18 \mu \mathrm{g} / \mathrm{kg}, 16.62 \pm 0.84 \mu \mathrm{g} / \mathrm{kg}$ for $\mathrm{H} 1, \mathrm{H} 2$, $\mathrm{H} 3$ and $\mathrm{H} 4$ 


\section{International Journal of Science and Research (IJSR) \\ ISSN (Online): 2319-7064}

Index Copernicus Value (2013): 6.14 | Impact Factor (2015): 6.391

Table 2: Evolution of the following parameters during storage of cowpea

\begin{tabular}{|c|c|c|c|c|c|c|c|}
\hline Parameters & During storage (month) & TSP & $\mathrm{H} 0$ & H1 & $\mathrm{H} 2$ & $\mathrm{H} 3$ & $\mathrm{H} 4$ \\
\hline \multirow{6}{*}{ MC (\%) } & 0 & $10,03 \pm 0,21^{\mathrm{aA}}$ & $10,03 \pm 0,21^{\mathrm{aA}}$ & $10,03 \pm 0,21^{\mathrm{aA}}$ & $10,03 \pm 0,21^{\mathrm{aA}}$ & $10,03 \pm 0,21^{\mathrm{aA}}$ & $10,03 \pm 0,21^{\mathrm{aA}}$ \\
\hline & 1 & $10,24 \pm 0,06^{\mathrm{bA}}$ & $10,03 \pm 0,06^{\mathrm{aA}}$ & $10,07 \pm 0,03^{\mathrm{abA}}$ & $10,03 \pm 0,06^{\mathrm{aA}}$ & $10,09 \pm 0,10^{\mathrm{abA}}$ & $10,00 \pm 0,10^{\mathrm{aA}}$ \\
\hline & 2 & $12,30 \pm 0,10^{\mathrm{bB}}$ & $10,22 \pm 0,02^{\mathrm{aA}}$ & $10,17 \pm 0,03^{\mathrm{aA}}$ & $10,18 \pm 0,03^{\mathrm{aA}}$ & $10,18 \pm 0,03^{\mathrm{aA}}$ & $10,17 \pm 0,01^{\mathrm{aA}}$ \\
\hline & 4,5 & $14,67 \pm 0,15^{\mathrm{bC}}$ & $11,17 \pm 0,06^{\mathrm{aB}}$ & $10,99 \pm 0,01^{\mathrm{aB}}$ & $11,05 \pm 0,06^{\mathrm{aB}}$ & $11,01 \pm 0,03^{\mathrm{aB}}$ & $10,99 \pm 0,01^{\mathrm{aB}}$ \\
\hline & 7 & - & $12,55 \pm 0,11^{\mathrm{bC}}$ & $11,63 \pm 0,06^{\mathrm{aC}}$ & $11,72 \pm 0,06^{\mathrm{aC}}$ & $11,54 \pm 0,04^{\mathrm{aC}}$ & $11,56 \pm 0,19^{\mathrm{aC}}$ \\
\hline & 8 & - & $14,10 \pm 0,11^{\mathrm{bC}}$ & $12,06 \pm 0,12^{\mathrm{aD}}$ & $12,10 \pm 0,10^{\mathrm{aD}}$ & $12,06 \pm 0,06^{\mathrm{aD}}$ & $11,83 \pm 0,14^{\mathrm{aC}}$ \\
\hline \multirow{6}{*}{ Aw } & 0 & $0,61 \pm 0,01^{\mathrm{aA}}$ & $0,61 \pm 0,01^{\mathrm{aA}}$ & $0,61 \pm 0,01^{\mathrm{aA}}$ & $0,61 \pm 0,01^{\mathrm{aA}}$ & $0,61 \pm 0,01^{\mathrm{aA}}$ & $0,61 \pm 0,01^{\mathrm{aA}}$ \\
\hline & 1 & $0,87 \pm 0,01^{\mathrm{bB}}$ & $0,62 \pm 0,01^{\mathrm{aA}}$ & $0,62 \pm 0,01^{\mathrm{aAB}}$ & $0,61 \pm 0,01^{\mathrm{aA}}$ & $0,61 \pm 0,00^{\mathrm{aA}}$ & $0,61 \pm 0,01^{\text {aA }}$ \\
\hline & 2 & $0,90 \pm 0,01^{\mathrm{cB}}$ & $0,68 \pm 0,01^{\mathrm{bB}}$ & $0,63 \pm 0,00^{\mathrm{aAB}}$ & $0,63 \pm 0,01^{\mathrm{aAB}}$ & $0,62 \pm 0,00^{\mathrm{aA}}$ & $0,62 \pm 0,01^{\mathrm{aAB}}$ \\
\hline & 4,5 & $0,96 \pm 0,01^{\mathrm{cC}}$ & $0,73 \pm 0,00^{\mathrm{bC}}$ & $0,64 \pm 0,01^{\mathrm{aB}}$ & $0,63 \pm 0,01^{\mathrm{aAB}}$ & $0,63 \pm 0,01^{\mathrm{aAB}}$ & $0,63 \pm 0,00^{\mathrm{aAB}}$ \\
\hline & 7 & - & $0,87 \pm 0,01^{\mathrm{cD}}$ & $0,71 \pm 0,01^{\mathrm{bC}}$ & $0,67 \pm 0,01^{\mathrm{aB}}$ & $0,65 \pm 0,01^{\mathrm{aB}}$ & $0,64 \pm 0,01^{\mathrm{aB}}$ \\
\hline & 8 & - & $0,92 \pm 0,00^{\mathrm{dE}}$ & $0,86 \pm 0,01^{\mathrm{cD}}$ & $0,86 \pm 0,01^{\mathrm{bC}}$ & $0,71 \pm 0,01^{\mathrm{abC}}$ & $0,70 \pm 0,01^{\mathrm{aC}}$ \\
\hline \multirow{6}{*}{$\begin{array}{l}\text { AFB1 } \\
(\mu \mathrm{g} / \mathrm{kg})\end{array}$} & 0 & $0,16 \pm 0,01^{\mathrm{aA}}$ & $0,16 \pm 0,01^{\mathrm{aA}}$ & $0,16 \pm 0,01^{\mathrm{aA}}$ & $0,16 \pm 0,01^{\mathrm{aA}}$ & $0,16 \pm 0,01^{\mathrm{aA}}$ & $0,16 \pm 0,01^{\mathrm{aA}}$ \\
\hline & 1 & $1,11 \pm 0,00^{\mathrm{bB}}$ & $0,17 \pm 0,01^{\mathrm{aA}}$ & $0,16 \pm 0,01^{\mathrm{aA}}$ & $0,17 \pm 0,00^{\mathrm{aA}}$ & $0,17 \pm 0,01^{\mathrm{aA}}$ & $0,17 \pm 0,01^{\mathrm{aA}}$ \\
\hline & 2 & $2,99 \pm 0,00^{\mathrm{dC}}$ & $0,52 \pm 0,00^{\mathrm{cA}}$ & $0,44 \pm 0,00^{\mathrm{bB}}$ & $0,20 \pm 0,01^{1 \mathrm{~A}}$ & $0,19 \pm 0,00^{\mathrm{aA}}$ & $0,20 \pm 0,01^{\mathrm{aB}}$ \\
\hline & 4,5 & $9,21 \pm 0,01^{\mathrm{dD}}$ & $1,17 \pm 0,03^{\mathrm{cB}}$ & $0,74 \pm 0,01^{\mathrm{bC}}$ & $0,52 \pm 0,01^{\mathrm{aB}}$ & $0,28 \pm 0,01^{\mathrm{aB}}$ & $0,27 \pm 0,00^{\mathrm{aC}}$ \\
\hline & 7 & - & $6,62 \pm 0,02^{\mathrm{dC}}$ & $1,12 \pm 0,01^{\mathrm{CD}}$ & $0,58 \pm 0,01^{\mathrm{bC}}$ & $0,46 \pm 0,01^{\mathrm{aC}}$ & $0,44 \pm 0,01^{\mathrm{aD}}$ \\
\hline & 8 & - & $8,41 \pm 0,48^{\mathrm{cD}}$ & $2,09 \pm 0,04^{\mathrm{bE}}$ & $1,31 \pm 0,01^{\mathrm{abD}}$ & $1,29 \pm 0,03^{\mathrm{aD}}$ & $1,14 \pm 0,01^{\mathrm{aE}}$ \\
\hline \multirow{6}{*}{$\begin{array}{c}\text { AFB2 } \\
(\mu \mathrm{g} / \mathrm{kg})\end{array}$} & 0 & $0,03 \pm 0,00^{\mathrm{aA}}$ & $0,03 \pm 0,00^{\mathrm{aA}}$ & $0,03 \pm 0,00^{\mathrm{aA}}$ & $0,03 \pm 0,00^{\mathrm{aA}}$ & $0,03 \pm 0,00^{\mathrm{aA}}$ & $0,03 \pm 0,00^{\mathrm{aA}}$ \\
\hline & 1 & $0,22 \pm 0,00^{\mathrm{bB}}$ & $0,03 \pm 0,00^{\mathrm{aA}}$ & $0,03 \pm 0,00^{\mathrm{aA}}$ & $0,03 \pm 0,01^{\mathrm{aAB}}$ & $0,03 \pm 0,01^{\mathrm{aA}}$ & $0,03 \pm 0,00^{\mathrm{aA}}$ \\
\hline & 2 & $0,32 \pm 0,00^{\mathrm{dC}}$ & $0,07 \pm 0,01^{\mathrm{cA}}$ & $0,04 \pm 0,00^{\mathrm{bA}}$ & $0,02 \pm 0,00^{\mathrm{abA}}$ & $0,02 \pm 0,00^{\mathrm{aA}}$ & $0,02 \pm 0,00^{\mathrm{abA}}$ \\
\hline & 4,5 & $1,00 \pm 0,01^{\mathrm{CD}}$ & $0,45 \pm 0,01^{\mathrm{bB}}$ & $0,05 \pm 0,01^{\mathrm{a} A}$ & $0,05 \pm 0,01^{\mathrm{aBC}}$ & $0,03 \pm 0,01^{\mathrm{aA}}$ & $0,02 \pm 0,00^{\mathrm{aA}}$ \\
\hline & 7 & - & $0,58 \pm 0,04^{\mathrm{cC}}$ & $0,12 \pm 0,01^{\mathrm{aB}}$ & $0,06 \pm 0,00^{\mathrm{aC}}$ & $0,41 \pm 0,01^{\mathrm{bB}}$ & $0,38 \pm 0,01^{\mathrm{bB}}$ \\
\hline & 8 & - & $1,03 \pm 0,06^{\mathrm{cD}}$ & $0,31 \pm 0,01^{\mathrm{aC}}$ & $0,20 \pm 0,01^{\mathrm{aD}}$ & $0,54 \pm 0,01^{\mathrm{bC}}$ & $0,46 \pm 0,01^{\mathrm{bC}}$ \\
\hline \multirow{6}{*}{$\begin{array}{c}\mathrm{AFG1} \\
(\mu \mathrm{g} / \mathrm{kg})\end{array}$} & 0 & $1,13 \pm 0,01^{\mathrm{aA}}$ & $1,13 \pm 0,01^{\mathrm{aA}}$ & $1,13 \pm 0,01^{\mathrm{aA}}$ & $1,13 \pm 0,01^{\mathrm{aAB}}$ & $1,13 \pm 0,01^{\mathrm{aAB}}$ & $1,13 \pm 0,01^{\mathrm{aA}}$ \\
\hline & 1 & $8,86 \pm 0,04^{\mathrm{bB}}$ & $1,02 \pm 0,01^{\mathrm{aA}}$ & $1,00 \pm 0,01^{\mathrm{aA}}$ & $0,99 \pm 0,01^{\mathrm{aA}}$ & $1,02 \pm 0,00^{\mathrm{aA}}$ & $1,00 \pm 0,01^{\mathrm{aA}}$ \\
\hline & 2 & $16,09 \pm 0,64^{\mathrm{cC}}$ & $4,21 \pm 0,01^{\mathrm{bA}}$ & $1,57 \pm 0,01^{\mathrm{aA}}$ & $1,32 \pm 0,00^{\mathrm{aB}}$ & $1,22 \pm 0,01^{\mathrm{aB}}$ & $1,20 \pm 0,00^{\mathrm{aA}}$ \\
\hline & 4,5 & $78,77 \pm 0,38^{\mathrm{CD}}$ & $15,03 \pm 0,22^{\mathrm{bB}}$ & $3,26 \pm 0,06^{\mathrm{aB}}$ & $2,95 \pm 0,04^{\mathrm{aC}}$ & $2,65 \pm 0,09^{\mathrm{aC}}$ & $2,59 \pm 0,02^{\mathrm{aB}}$ \\
\hline & 7 & - & $43,69 \pm 1,01^{\mathrm{cC}}$ & $8,25 \pm 0,03^{\mathrm{bC}}$ & $4,62 \pm 0,03^{\mathrm{aD}}$ & $3,95 \pm 0,04^{\mathrm{aD}}$ & $3,92 \pm 0,05^{\mathrm{aC}}$ \\
\hline & 8 & - & $61,50 \pm 2,80^{\mathrm{cD}}$ & $15,40 \pm 0,40^{\mathrm{bD}}$ & $14,10 \pm 0,16^{\mathrm{abE}}$ & $11,10 \pm 0,07^{\mathrm{abE}}$ & $9,79 \pm 0,80^{\mathrm{aD}}$ \\
\hline \multirow{6}{*}{$\begin{array}{c}\mathrm{AFG} 2 \\
(\mu \mathrm{g} / \mathrm{kg})\end{array}$} & 0 & $0,98 \pm 0,01^{\mathrm{aA}}$ & $0,98 \pm 0,01^{\mathrm{aA}}$ & $0,98 \pm 0,01^{\mathrm{aA}}$ & $0,98 \pm 0,01^{\mathrm{aA}}$ & $0,98 \pm 0,01^{\mathrm{aA}}$ & $0,98 \pm 0,01^{\mathrm{aA}}$ \\
\hline & 1 & $5,98 \pm 0,00^{\mathrm{bB}}$ & $0,91 \pm 0,01^{\mathrm{aA}}$ & $0,89 \pm 0,02^{\mathrm{aA}}$ & $0,91 \pm 0,02^{\mathrm{aA}}$ & $0,91 \pm 0,01^{\mathrm{aA}}$ & $0,92 \pm 0,01^{\mathrm{aA}}$ \\
\hline & 2 & $13,47 \pm 0,41^{\mathrm{cC}}$ & $2,05 \pm 0,03^{\mathrm{bA}}$ & $1,23 \pm 0,01^{\mathrm{aB}}$ & $1,02 \pm 0,00^{\mathrm{aA}}$ & $0,98 \pm 0,00^{\mathrm{aA}}$ & $1,00 \pm 0,01^{\mathrm{aA}}$ \\
\hline & 4,5 & $56,90 \pm 0,47^{\mathrm{dD}}$ & $11,95 \pm 0,15^{\mathrm{cB}}$ & $1,15 \pm 0,04^{\mathrm{aB}}$ & $2,03 \pm 0,04^{\mathrm{bB}}$ & $1,99 \pm 0,01^{\mathrm{bB}}$ & $2,02 \pm 0,02^{\mathrm{aB}}$ \\
\hline & 7 & - & $21,99 \pm 0,79^{\mathrm{cC}}$ & $3,19 \pm 0,05^{\mathrm{bC}}$ & $1,23 \pm 0,01^{\mathrm{aA}}$ & $1,01 \pm 0,01^{\mathrm{aA}}$ & $1,00 \pm 0,02^{\mathrm{aA}}$ \\
\hline & 8 & - & $26,77 \pm 2,11^{\mathrm{cD}}$ & $11,13 \pm 0,01^{\mathrm{bD}}$ & $9,42 \pm 0,28^{\mathrm{bC}}$ & $1,29 \pm 0,03^{\mathrm{abC}}$ & $5,51 \pm 0,35^{\mathrm{aC}}$ \\
\hline \multirow{6}{*}{$\operatorname{AFT}(\mu \mathrm{g} / \mathrm{kg})$} & 0 & $2,30 \pm 0,01^{\mathrm{aA}}$ & $2,30 \pm 0,01^{\mathrm{aA}}$ & $2,30 \pm 0,01^{\mathrm{aA}}$ & $2,30 \pm 0,01^{\mathrm{aA}}$ & $2,30 \pm 0,01^{\mathrm{aA}}$ & $2,30 \pm 0,01^{\mathrm{aA}}$ \\
\hline & 1 & $16,17 \pm 0,05^{\mathrm{bB}}$ & $2,13 \pm 0,02^{\mathrm{aA}}$ & $2,08 \pm 0,02^{\mathrm{aA}}$ & $2,11 \pm 0,02^{\mathrm{aA}}$ & $2,13 \pm 0,02^{\mathrm{aA}}$ & $2,11 \pm 0,01^{\mathrm{aA}}$ \\
\hline & 2 & $32,87 \pm 0,87^{\mathrm{CC}}$ & $6,85 \pm 0,03^{\mathrm{bA}}$ & $3,08 \pm 0,02^{\mathrm{aB}}$ & $2,56 \pm 0,01^{\mathrm{aA}}$ & $2,41 \pm 0,01^{\mathrm{aA}}$ & $2,43 \pm 0,02^{\mathrm{aA}}$ \\
\hline & 4,5 & $145,87 \pm 0,88^{\mathrm{cD}}$ & $25,61 \pm 5,55^{\mathrm{bB}}$ & $4,90 \pm 0,07^{\mathrm{aC}}$ & $5,35 \pm 0,07^{\mathrm{aB}}$ & $4,95 \pm 0,10^{\mathrm{aB}}$ & $4,90 \pm 0,04^{\mathrm{aB}}$ \\
\hline & 7 & 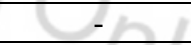 & $72,52 \pm 1,79^{\mathrm{cC}}$ & $12,68 \pm 0,04^{\mathrm{bD}}$ & $6,49 \pm 0,05^{\mathrm{aC}}$ & $5,84 \pm 0,03^{\mathrm{aC}}$ & $7,73 \pm 0,03^{\mathrm{aB}}$ \\
\hline & 8 & - & $97,71 \pm 0,55^{\mathrm{eD}}$ & $28,92 \pm 0,43^{\mathrm{dE}}$ & $25,23 \pm 0,34^{\mathrm{CD}}$ & $20,59 \pm 0,18^{\mathrm{bD}}$ & $16,62 \pm 0,84^{\mathrm{aC}}$ \\
\hline
\end{tabular}

The mean $( \pm S D)$ with different lowercase / uppercase letters on the same line / in the same column are different test probability of 5\%, MC: moisture, Aw: water activity, AFB1: aflatoxin B1, AFB2: Aflatoxin B2, AFG1: aflatoxin G1, AFG2: Aflatoxin G2, AFT: total aflatoxins; TSP = Control without PICS bag (polypropylene bag); HO = Control with PICS bag (no biopesticide); $\boldsymbol{H 1}=$ PICS bag with $0.7 \%$ of biopesticide $(w / w) ; \boldsymbol{H 2}=$ PICS bag with $2.5 \%$ biopesticide $(w / w) ; \quad \boldsymbol{H} \mathbf{3}=$ PICS bag with $4.3 \%$ of biopesticide $(w / w) ; \boldsymbol{H} \mathbf{4}=$ PICS bag with 5.0\% of biopesticide ( $w / w)$

Table 3: Statistical data for moisture, water activity and aflatoxins in cowpea grains according to the type of packaging during the storage period

\begin{tabular}{|c|c|c|c|c|c|c|c|c|c|}
\hline \multirow{2}{*}{$\begin{array}{l}\text { Source of } \\
\text { Variation }\end{array}$} & \multirow[t]{2}{*}{$\mathrm{df}$} & & & \multicolumn{6}{|c|}{ Parameters } \\
\hline & & & $\mathrm{MC}$ & Aw & AFB1 & AFB2 & AFG1 & AFG2 & AFT \\
\hline \multirow[t]{3}{*}{ Types } & \multirow[t]{3}{*}{5} & SS & 26,21 & 0,563 & 179,75 & 2,12 & 9938,59 & 4097,94 & 31233,55 \\
\hline & & F-value & 394,75 & 696,49 & 3025,50 & 1044,70 & 3833,30 & 2770,89 & 3365,81 \\
\hline & & P-value & $<0,001$ & $<0,001$ & $<0,001$ & $<0,001$ & $<0,001$ & $<0,001$ & $<0,001$ \\
\hline \multirow[t]{3}{*}{ Duration } & \multirow[t]{3}{*}{5} & SS & 97,55 & 0,42 & 132,34 & 3,51 & 8471,57 & 2930,77 & 24790,47 \\
\hline & & F-value & 1469,06 & 517,76 & 2227,43 & 1728,29 & 3267,47 & 1981,69 & 2671,48 \\
\hline & & P-value & $<0,001$ & $<0,001$ & $<0,001$ & $<0,001$ & $<0,001$ & $<0,001$ & $<0,001$ \\
\hline \multirow{3}{*}{$\begin{array}{l}\text { Types } \mathrm{x} \\
\text { duration }\end{array}$} & \multirow[t]{3}{*}{23} & SS & 30,78 & 0,27 & 223,06 & 2,29 & 13987,22 & 5489,90 & 43121,34 \\
\hline & & F-value & 100,75 & 72,46 & 816,17 & 244,73 & 1172,79 & 806,97 & 1010,19 \\
\hline & & P-value & $<0,001$ & $<.0,001$ & $<0,001$ & $<0,001$ & $<0,001$ & $<0,001$ & $<0,001$ \\
\hline Error & 68 & SS & 0,90 & 0,01 & 0,81 & 0,03 & 35,26 & 20,11 & 126,20 \\
\hline Total & 102 & SS & 12543,21 & 49,25 & 667,84 & 667,84 & 399464 & 15469,70 & 122390,33 \\
\hline
\end{tabular}

Volume 5 Issue 7, July 2016 www.ijsr.net

Licensed Under Creative Commons Attribution CC BY 


\section{International Journal of Science and Research (IJSR) \\ ISSN (Online): 2319-7064}

Index Copernicus Value (2013): 6.14 | Impact Factor (2015): 6.391

SS: sum of squares; $\boldsymbol{F}$-value: value of the statistical test; P-value: probability value of the statistical test; $\boldsymbol{d}$ : degree of freedom; $\boldsymbol{M C}$ : moisture; Aw: water activity; AFB1: aflatoxin B1; AFB2: Aflatoxin B2; AFG1: aflatoxin G1; AFG2: Aflatoxin G2; AFT: total aflatoxins

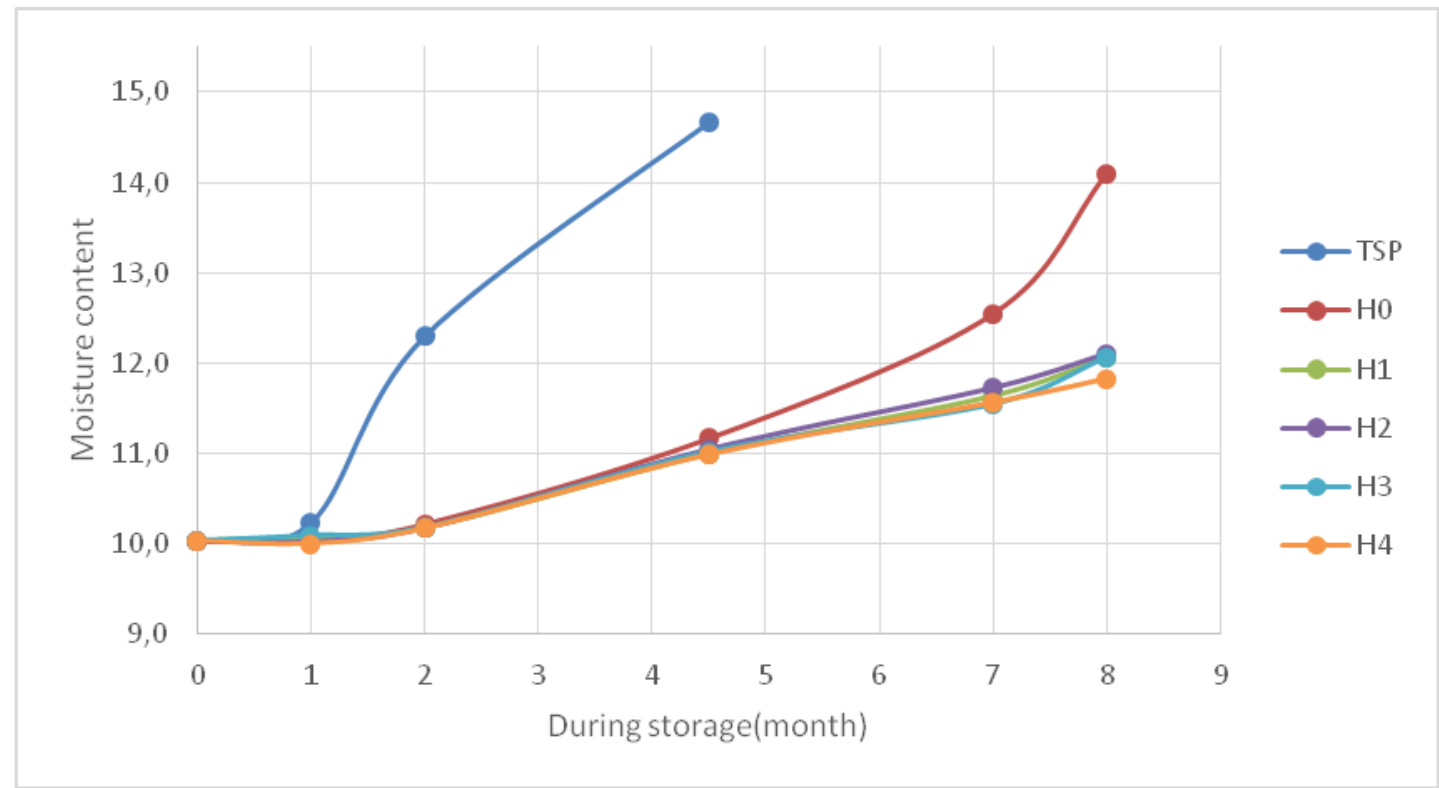

Figure 1: Evolution of moisture content during storage

TSP $=$ Control without PICS bag (polypropylene bag)

$\mathrm{H} 0=$ Control with PICS bag (no biopesticide)

H1 $=$ PICS bag with $0.7 \%$ of biopesticide $(\mathrm{w} / \mathrm{w})$

$\mathrm{H} 2=$ PICS bag with $2.5 \%$ biopesticide $(\mathrm{w} / \mathrm{w})$

$\mathrm{H} 3=\mathrm{PICS}$ bag with $4.3 \%$ of biopesticide $(\mathrm{w} / \mathrm{w})$

$\mathrm{H} 4=\mathrm{PICS}$ bag with $5.0 \%$ of biopesticide $(\mathrm{w} / \mathrm{w})$

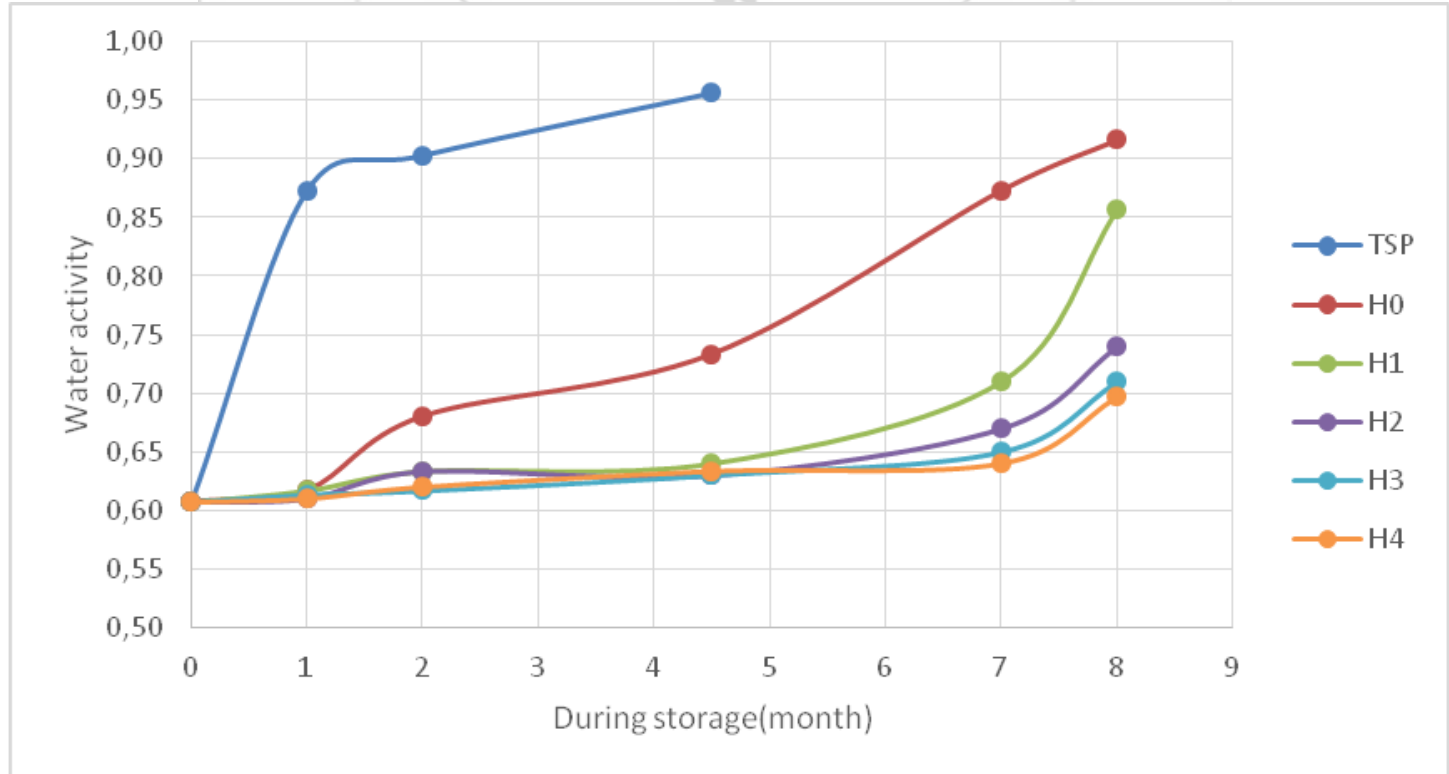

Figure 2: Evolution of water activity during storage

Volume 5 Issue 7, July 2016

www.ijsr.net

Licensed Under Creative Commons Attribution CC BY 


\section{International Journal of Science and Research (IJSR) \\ ISSN (Online): 2319-7064}

Index Copernicus Value (2013): 6.14 | Impact Factor (2015): 6.391

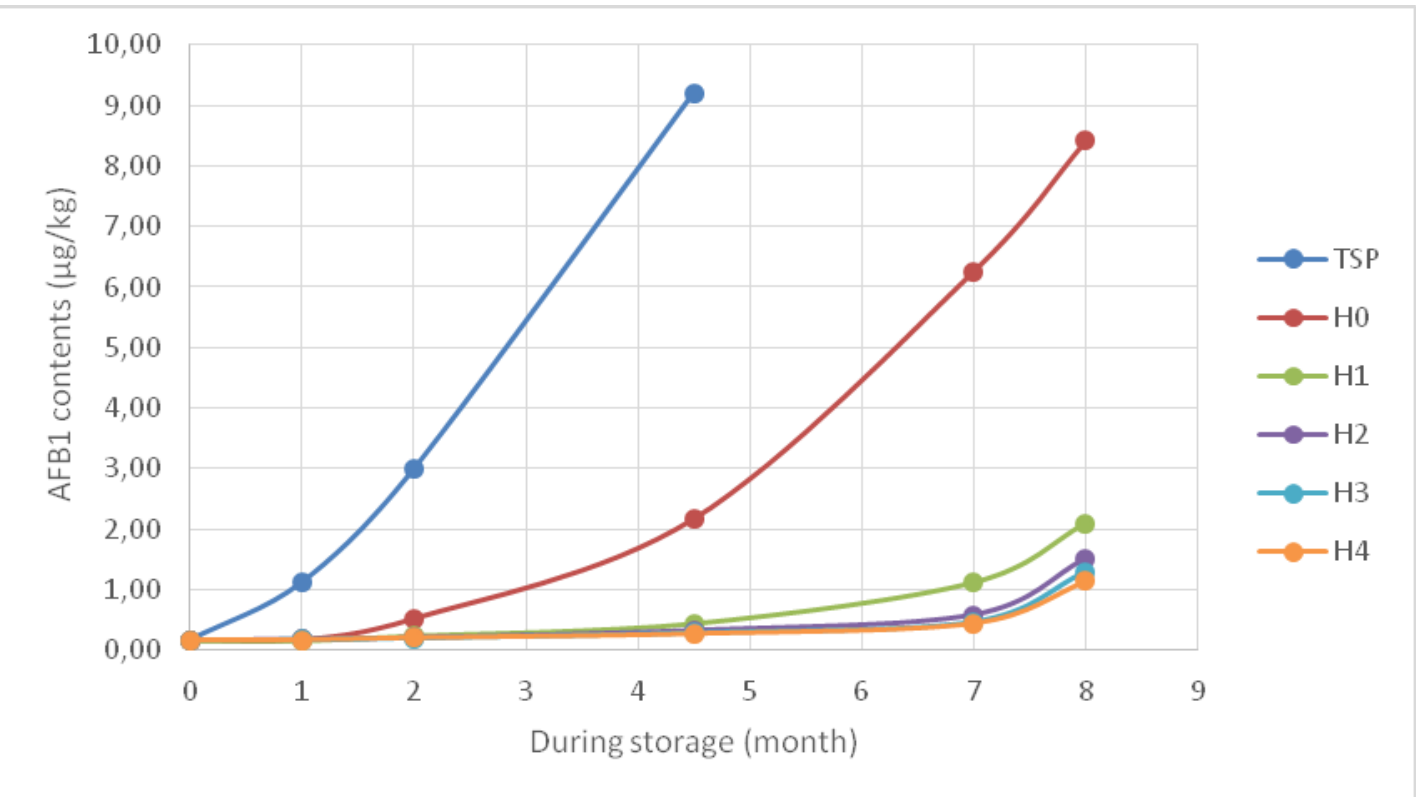

Figure 3: Evolution of Aflatoxins B1 contents during storage

TSP $=$ Control without PICS bag (polypropylene bag)

$\mathrm{H} 0=$ Control with PICS bag (no biopesticide)

$\mathrm{H} 1=$ PICS bag with $0.7 \%$ of biopesticide $(\mathrm{w} / \mathrm{w})$

$\mathrm{H} 2=$ PICS bag with $2.5 \%$ biopesticide $(\mathrm{w} / \mathrm{w})$

$\mathrm{H} 3=$ PICS bag with $4.3 \%$ of biopesticide $(\mathrm{w} / \mathrm{w})$

$\mathrm{H} 4=$ PICS bag with $5.0 \%$ of biopesticide $(\mathrm{w} / \mathrm{w})$

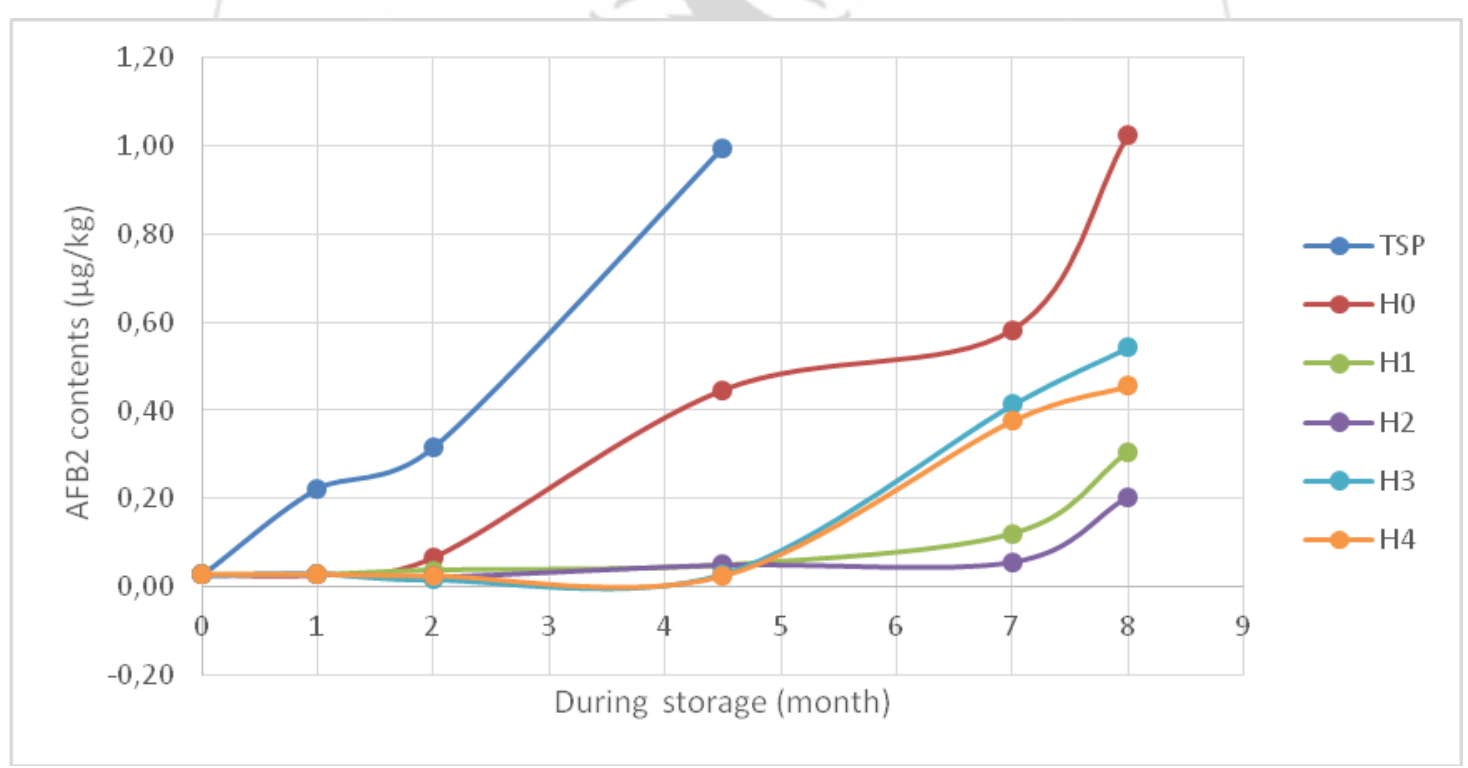

Figure 4: Evolution of Aflatoxins B2 contents during storage

Volume 5 Issue 7, July 2016

www.ijsr.net

Licensed Under Creative Commons Attribution CC BY 


\section{International Journal of Science and Research (IJSR) \\ ISSN (Online): 2319-7064}

Index Copernicus Value (2013): 6.14 | Impact Factor (2015): 6.391

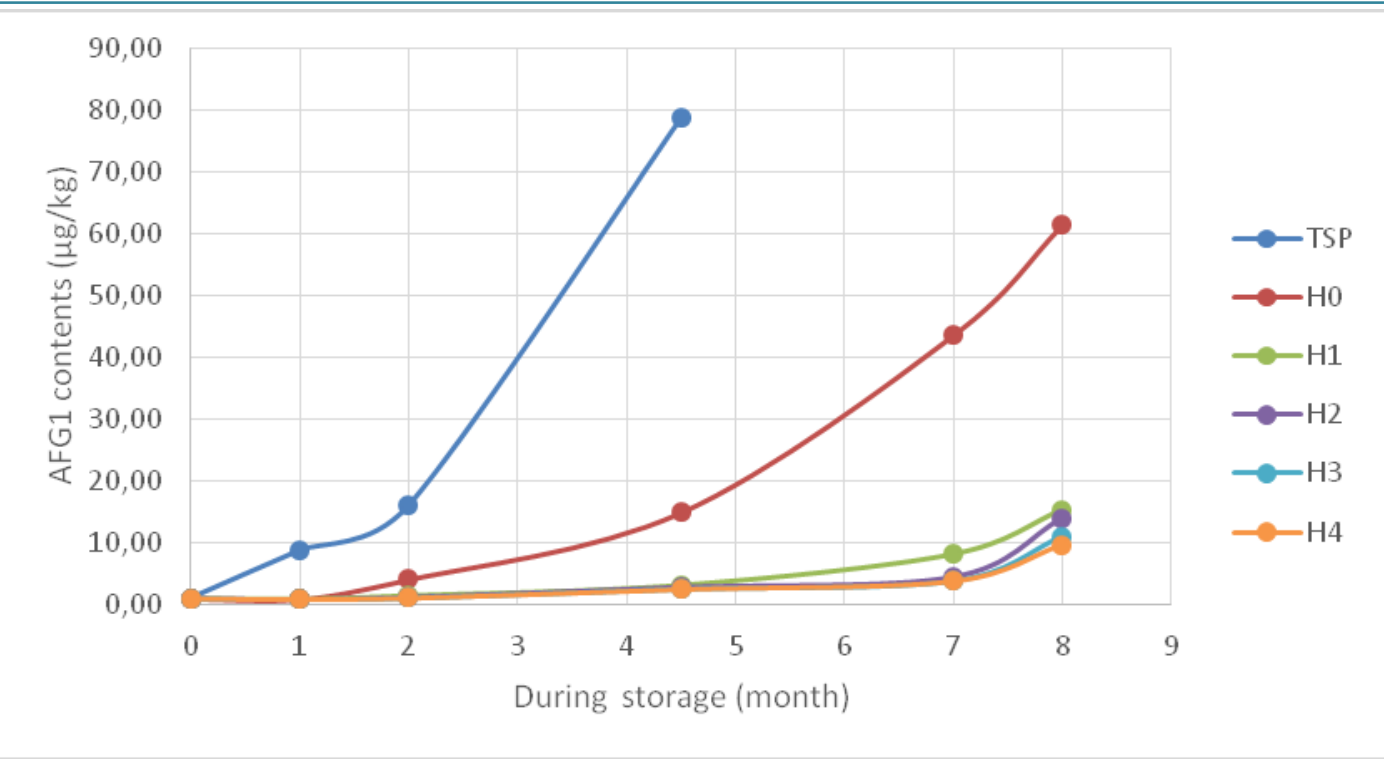

Figure 5: Evolution of Aflatoxins G1 contents during storage

TSP $=$ Control without PICS bag (polypropylene bag)

$\mathrm{H} 0=$ Control with PICS bag (no biopesticide)

$\mathrm{H} 1=\mathrm{PICS}$ bag with $0.7 \%$ of biopesticide $(\mathrm{w} / \mathrm{w})$

$\mathrm{H} 2=$ PICS bag with $2.5 \%$ biopesticide $(\mathrm{w} / \mathrm{w})$

$\mathrm{H} 3=\mathrm{PICS}$ bag with $4.3 \%$ of biopesticide $(\mathrm{w} / \mathrm{w})$

$\mathrm{H} 4=$ PICS bag with $5.0 \%$ of biopesticide $(\mathrm{w} / \mathrm{w})$

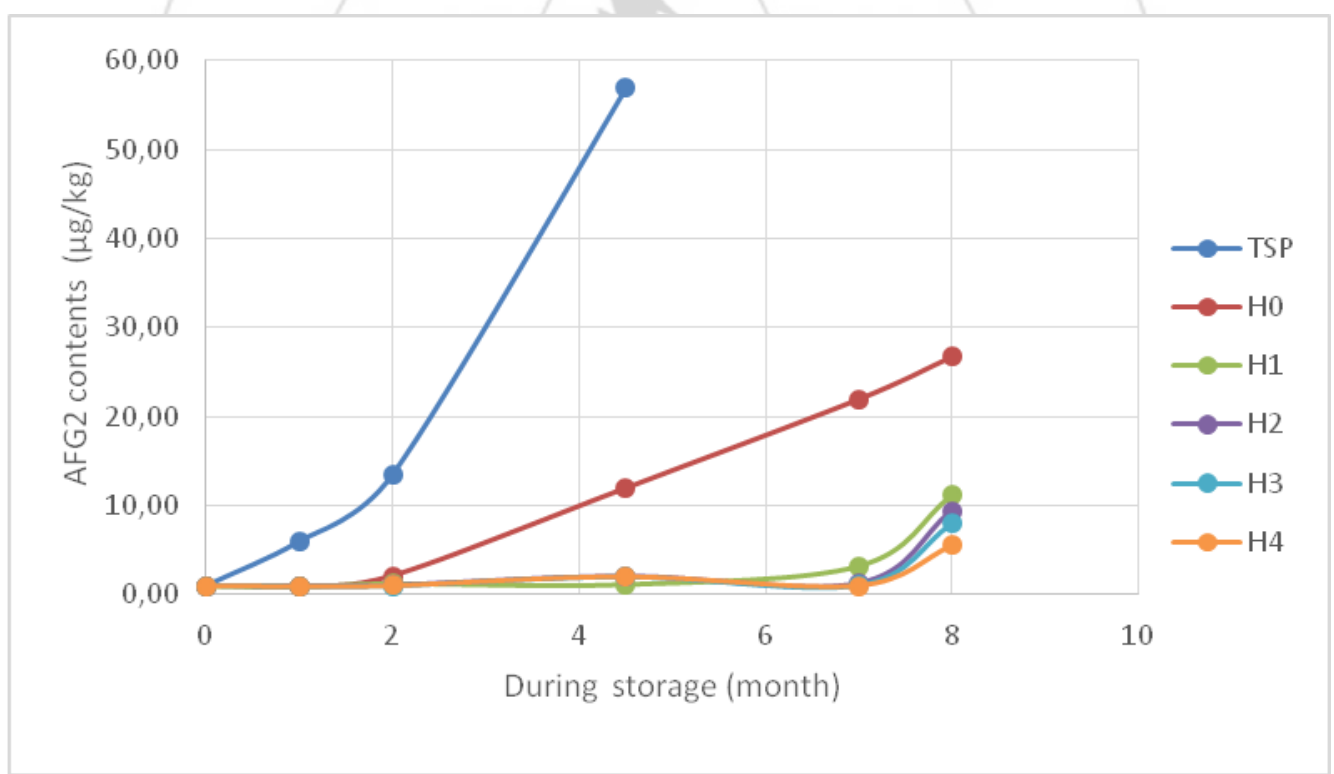

Figure 6: Evolution of Aflatoxins G2 contents during storage

Volume 5 Issue 7, July 2016

www.ijsr.net

Licensed Under Creative Commons Attribution CC BY 


\section{International Journal of Science and Research (IJSR)}

ISSN (Online): 2319-7064

Index Copernicus Value (2013): 6.14 | Impact Factor (2015): 6.391

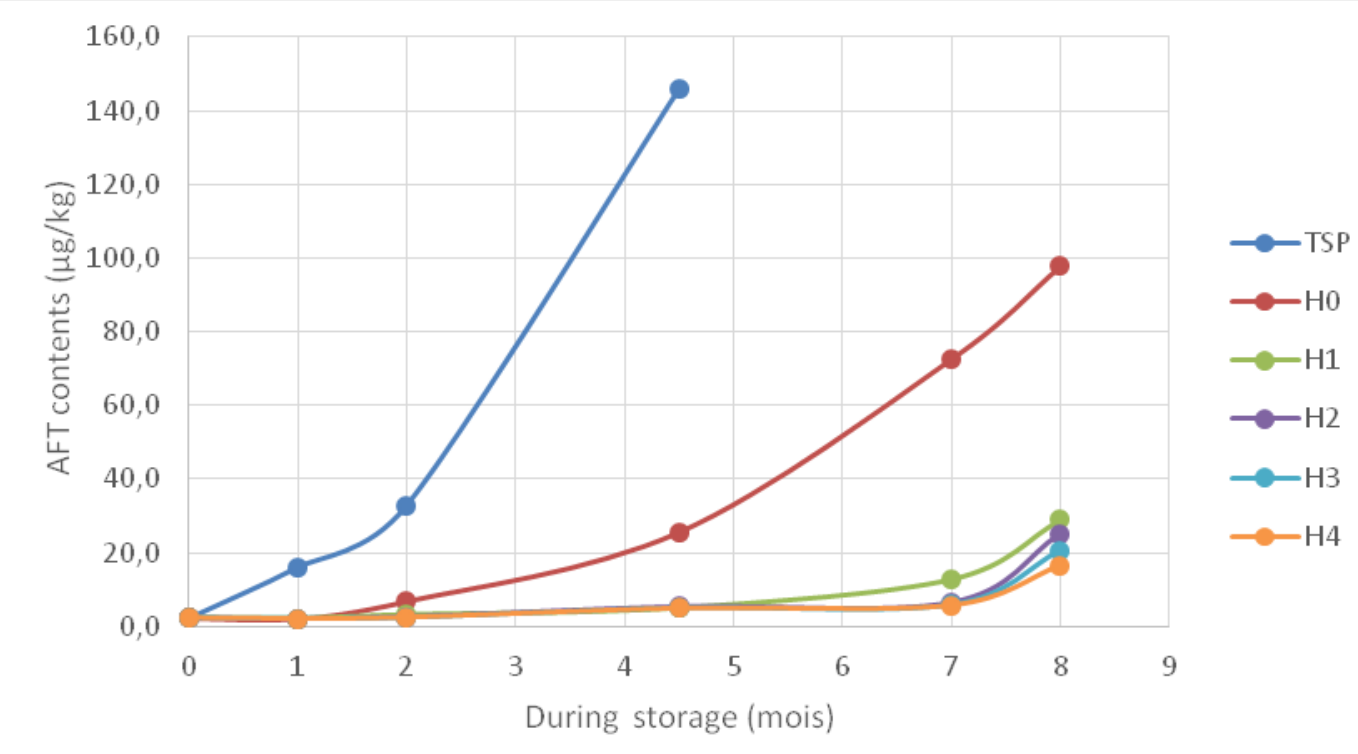

Figure 7: Evolution of totals Aflatoxins contents during storage

TSP $=$ Control without PICS bag (polypropylene bag)

$\mathrm{H} 0=$ Control with PICS bag (no biopesticide)

$\mathrm{H} 1=\mathrm{PICS}$ bag with $0.7 \%$ of biopesticide $(\mathrm{w} / \mathrm{w})$

$\mathrm{H} 2=$ PICS bag with $2.5 \%$ biopesticide $(\mathrm{w} / \mathrm{w})$

$\mathrm{H} 3=\mathrm{PICS}$ bag with $4.3 \%$ of biopesticide $(\mathrm{w} / \mathrm{w})$

$\mathrm{H} 4=\mathrm{PICS}$ bag with $5.0 \%$ of biopesticide $(\mathrm{w} / \mathrm{w})$

\subsection{Correlations between humidity, water activity and the levels of aflatoxins}

Table 4 depicts the correlation between moisture, water activity and the levels of aflatoxins (AFB1, AFB2, AFG1, AFG2 and AFT) in different types of packaging. Indexes (Pearson r) indicate positive and significant correlation between the seven parameters studied for different types of packaging. Thus, humidity, water activity and the levels of aflatoxins (AFB1, AFB2, AFG1, AFG2 and AFT) are closely correlated during storage of cowpea, with $\mathrm{r}$ varying from 0.79 to 0.99 . In addition, moisture and water activity change closely $(r=0.79)$. The aflatoxin $\mathrm{B} 1$ content is directly correlated with aflatoxin G1 $(r=0.99)$. significant positive correlations were found between aflatoxin $\mathrm{B} 1$ and aflatoxin $\mathrm{G} 2(\mathrm{r}=0.84)$. This same observation is also made between total aflatoxins and water activity $(\mathrm{r}=0.83)$.

Table 4: Matrix of Pearson correlation indexes between moisture, water activity and aflatoxins during storage

\begin{tabular}{|c|c|c|c|c|c|c|c|}
\hline & MC & Aw & AFB1 & AFB2 & AFG1 & AFG2 & AFT \\
\hline MC & 1 & & & & & & \\
\hline Aw & 0,79 & 1 & & & & & \\
\hline AFB1 & 0,87 & 0,84 & 1 & & & & \\
\hline AFB2 & 0,89 & 0,78 & 0,88 & 1 & & & \\
\hline AFG1 & 0,87 & 0,82 & 0,99 & 0,89 & 1 & & \\
\hline AFG2 & 0,84 & 0,81 & 0,94 & 0,84 & 0,97 & 1 & \\
\hline AFT & 0,87 & 0,83 & 0,98 & 0,88 & 1,00 & 0,98 & 1 \\
\hline
\end{tabular}

The values are significant at $P=0.05 ; \mathrm{MC}:$ moisture content; $\boldsymbol{A w}$ : water activity, $\boldsymbol{A F B 1}$ : aflatoxin B1, AFB2 : aflatoxin B2, AFG1 : aflatoxin $G 1, \boldsymbol{A F G} 2$ : aflatoxin $G 2, \boldsymbol{A F T}$ : Total aflatoxins
3.6. Variability between types of packaging, moisture, water activity and the levels of aflatoxins

Variability among the parameters studied of cowpea and storage types was structured, first, by a principal component analysis (PCA). These analyzes were performed with the component (or factor) $\mathrm{F} 1$ which recorded an intrinsic value greater than 1, according to Kaïser rule (Table 5). Global parameters show significant negative correlations with F1. However, the component F2 (own value 0.26 ) is associated with $\mathrm{F} 1$ for the realization of PCA.

Figure 8.a shows the factors of the correlation circle of principal components analysis to other parameters of the stored cowpea. The first two factors (F1 and F2) have values 6.30 and 0.26 respectively. They express $93.82 \%$ of the variability (Table 5). The projection of the characters and individuals is made in the plane formed by the factors 1 and 2 (Figure 8.b). There divided individuals into 4 groups. Group 1 consists only of the control without PICS at 4.5 months storage (noted TSP5) whose parameters are different from others. Thus, it is characterized by the highest values of the levels of aflatoxins, moisture and water activity. The second group or individual is a control with PICS to 8 months of storage (H08). The characteristics of its parameters differ from other individuals. Its parameters have similar trends to those of TSP5 with slightly lower values than those of TSP5. The third group is also an individual who is a control with PICS without biopesticide to 7 months (H07). The characteristics of its parameters differ from other individuals. Its parameters were slightly below those of H08. The fourth group contains all samples PICS bags with biopesticide storage every month, control bag with PICS and without 


\section{International Journal of Science and Research (IJSR) \\ ISSN (Online): 2319-7064 \\ Index Copernicus Value (2013): 6.14 | Impact Factor (2015): 6.391}

biopesticide 1, 2 and 4.5 months (H01, H02, H05) and controls without PICS bags 1 and 2 months (TSP1 and TSP2). This group is characterized by low levels of aflatoxins (AFB1, AFB2, AFG1 and AFG2), moisture and water activity.

The Ascending hierarchical classification (AHC) confirms the observed variability in the PCA (Figure 9). Indeed, the aggregate distance of 16 , the dendrogram indicates four classes observed during storage of cowpea. The first class consists of one individual TSP5 while the control bag with PICS to 8 months is the second class (H08). The third class is the PICS control bag to 7 months (H07). These individuals are distinguished separately with high values of the parameters studied. The fourth class includes all PICS bags biopestide, the PICS control bags with 1, 2 and 4.5 months and control bags without PICS at 1 and 2 months. Individuals in the latter group have low values of parameters and substantially similar.

Table 5: Matrix of eigenvalues of factors resulting from the Principal Components Analysis and correlation with the moisture content, the water activity and the aflatoxins levels of the cowpea stored for 8 months

\begin{tabular}{|l|c|c|c|c|c|c|c|}
\hline & Fact. 1 & Fact. 2 & Fact. 3 & Fact. 4 & Fact. 5 & Fact. 6 & Fact. 7 \\
\hline Eigenvalues & 6,30 & 0,26 & 0,25 & 0,11 & 0,06 & 0,00 & 0,00 \\
\hline Variance (\%) & 90,05 & 3,77 & 3,61 & 1,61 & 0,91 & 0,05 & 0,00 \\
\hline Cumulative Variance (\%) & 90,05 & 93,82 & 97,43 & 99,04 & 99,95 & 100,00 & 100,00 \\
\hline MC & $\mathbf{- 0 , 9 2}$ & 0,21 & $-0,24$ & 0,23 & 0,00 & 0,00 & 0,00 \\
\hline Aw & $\mathbf{- 0 , 8 8}$ & 0,31 & 0,35 & $-0,02$ & $-0,01$ & 0,00 & 0,00 \\
\hline AFB1 & $\mathbf{- 0 , 9 8}$ & $-0,11$ & 0,04 & $-0,01$ & 0,17 & $-0,04$ & 0,00 \\
\hline AFB2 & $\mathbf{- 0 , 9 3}$ & 0,15 & $-0,25$ & $-0,24$ & $-0,04$ & 0,00 & 0,00 \\
\hline AFG1 & $\mathbf{- 0 , 9 9}$ & $-0,15$ & 0,00 & $-0,01$ & 0,06 & 0,04 & 0,01 \\
\hline AFG2 & $\mathbf{- 0 , 9 6}$ & $-0,20$ & 0,07 & 0,04 & $-0,17$ & $-0,02$ & 0,00 \\
\hline AFT & $\mathbf{- 0 , 9 9}$ & $-0,16$ & 0,03 & 0,01 & $-0,01$ & 0,01 & $-0,01$ \\
\hline
\end{tabular}

Values of significant correlations in bold at $P=0.05 ; \boldsymbol{A w}:$ water activity, $\boldsymbol{A F B 1}:$ aflatoxin $B 1, \boldsymbol{A F B 2}:$ aflatoxin B2, $\boldsymbol{A F G 1}:$ aflatoxin G1, AFG2 : aflatoxin G2, AFT : Total aflatoxins

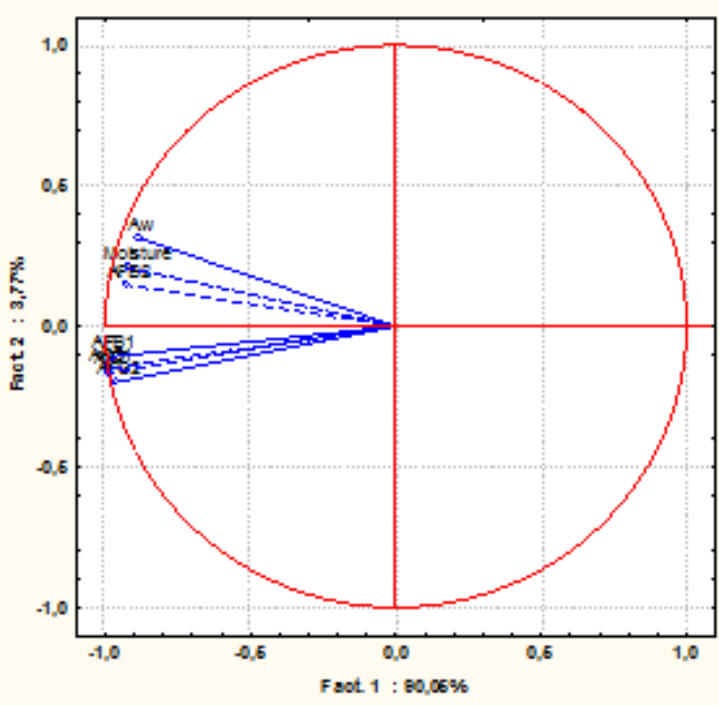

(a)

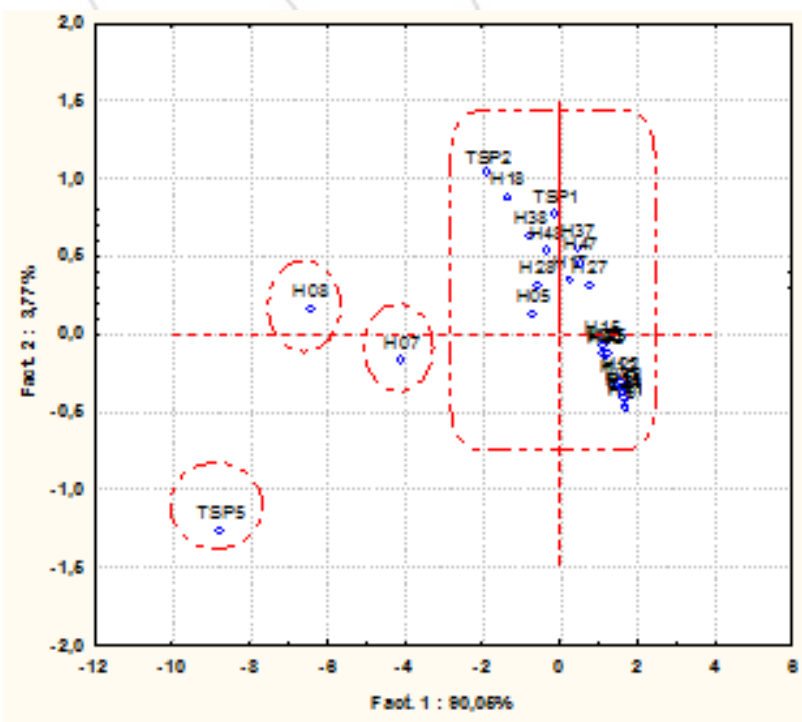

(b)

Figure 8: Correlation drawn between the F1-F2 factorial of the principal components analysis and the chemical parameters (a) and the individuals (b) deriving from the cowpea samples studied 


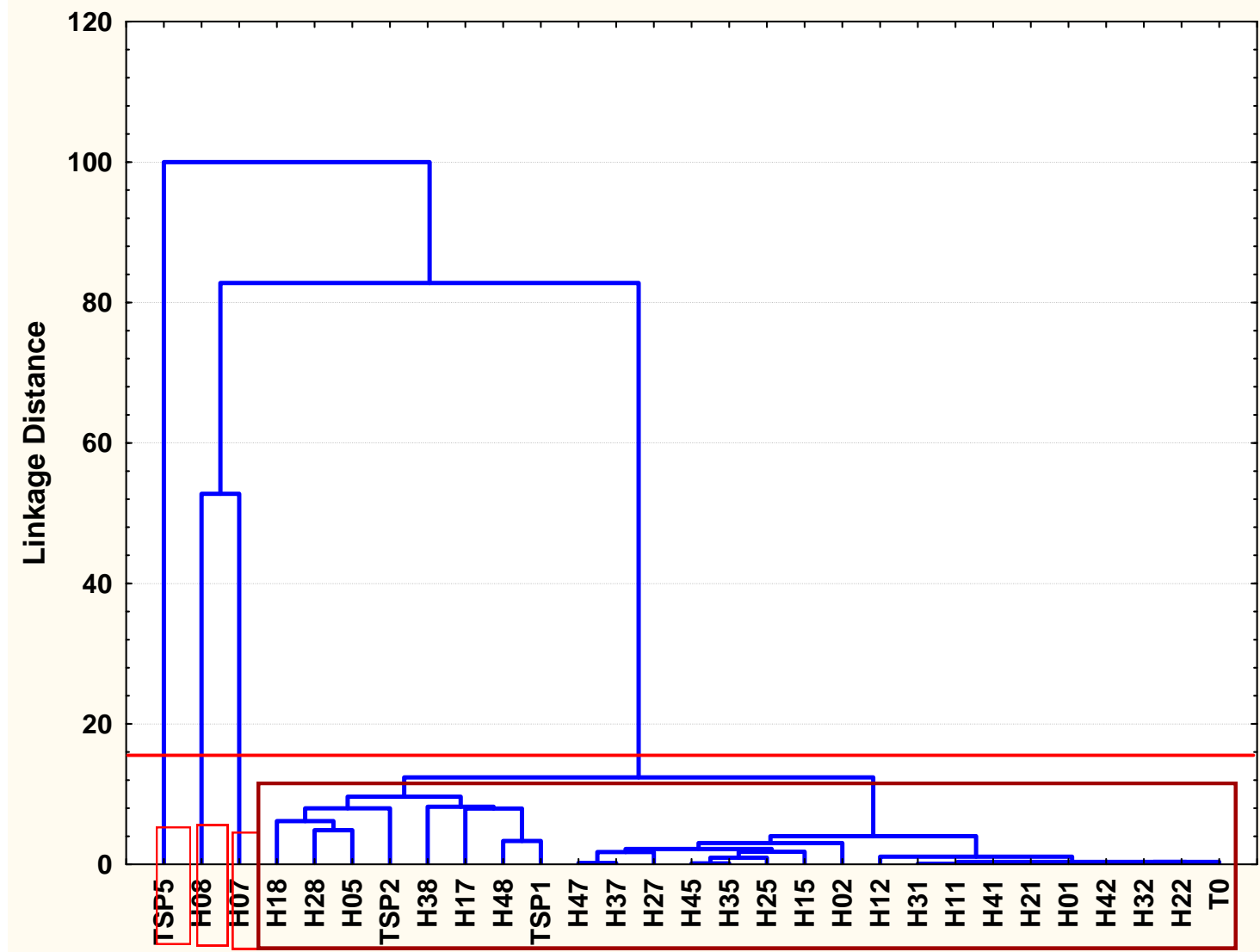

Figure 9: Dendrogram deriving with the ascending hierarchical classification of cowpea samples stored for 8 months according to the parameters assessed

T0: initial sample before storage, TSP (1 to 4,5 months) = Control without PICS bag (polypropylene bag), $\mathrm{HO}$ (1 to 8 months) = Control with PICS bag (no biopesticide), H1 (1 to 8 months) = PICS bag with $0.7 \%$ of biopesticide ( $w / w)$, $\mathbf{H} 2$ (1 to 8 months) = PICS bag with $2.5 \%$ biopesticide $(w / w), \mathbf{H 3}$ (1 to 8 months) $=$ PICS bag with $4.3 \%$ of biopesticide $(w / w), \boldsymbol{H} 4$ (1 to 8 months) $=$ PICS bag with $5.0 \%$ of biopesticide $(w / w)$

\subsection{Assessment of aflatoxins intake from cowpea beans} after-storage

Table 6 shows the estimation of aflatoxin B1 and total aflatoxins exposure from consumption of cowpea grains stored for 8 months. With daily consumption of cowpea 4.93 $\mathrm{g} /$ day in the Côte d'Tvoire, the intake estimated total aflatoxins were respectively $6.88 \pm 0.04 \mathrm{ng} / \mathrm{kg}, 2.04 \pm 0.03$ $\mathrm{ng} / \mathrm{kg}, 178 \pm 0.02 \mathrm{ng} / \mathrm{kg}, 1.45 \pm 0.01 \mathrm{ng} / \mathrm{kg}, 1.17 \pm 0.06$ $\mathrm{ng} / \mathrm{kg}$ body weight / day for $\mathrm{H} 0, \mathrm{H} 1, \mathrm{H} 2, \mathrm{H} 3$ and $\mathrm{H} 4$. Regarding exposure to aflatoxin B1 for the stored cowpea consumption, we estimated the contributions of $0.59 \pm 0.03$ $\mathrm{ng} / \mathrm{kg}$, bw / day, $0.15 \pm 0.00 \mathrm{ng} / \mathrm{kg}$ body weight / day; $0.09 \pm$ $0.00 \mathrm{ng} / \mathrm{kg} \mathrm{bw} /$ day; $0.09 \pm 0.00 \mathrm{ng} / \mathrm{kg}$ body weight/day and $0.08 \pm 0.00 \mathrm{ng} / \mathrm{kg}$ body weight / day respectively for H0, H1, $\mathrm{H} 2, \mathrm{H} 3$ and H4. Compared to the toxicity reference value $(0.15 \mathrm{ng} / \mathrm{kg}$ body weight/day), exposures are at least 7.8 times and at most 45.88 times higher for total aflatoxins and at least 0.53 and at most 3.95 higher for aflatoxin B1

Estimates of the total aflatoxins exposure and aflatoxin B1 to the control without PICS (TSP) have not been calculated because its shelf life could not reach 8 months. At 4.5 months of storage pests have created significant damage such as market and hygienic qualities so it was removed from storage.

Some values exhibitions aflatoxin B1 and total aflatoxins are higher than the maximum levels set by European Union. These values exceed the set standards that are $5 \mu \mathrm{g} / \mathrm{kg}$ for aflatoxin B1 and $10 \mu \mathrm{g} / \mathrm{kg}$ for AFT represent $8.82 \%$ and $29.41 \%$ of the total samples.

Table 6: Aflatoxins intake estimated from the consumption of cowpea grains from Ivorian adult (intake ng/kg body weight/day)

\begin{tabular}{|c|c|c|c|c|c|c|c|c|c|c|}
\hline & \multicolumn{5}{|c|}{ AFB1 } & \multicolumn{5}{|c|}{ AFT } \\
\hline & $\mathrm{H} 0$ & H1 & $\mathrm{H} 2$ & $\mathrm{H} 3$ & $\mathrm{H} 4$ & $\mathrm{H} 0$ & H1 & $\mathrm{H} 2$ & $\mathrm{H} 3$ & $\mathrm{H} 4$ \\
\hline Estimated Intake (EI) & $\begin{array}{c}0,59 \\
\pm 0,03 \\
\end{array}$ & $\begin{array}{c}0,15 \\
\pm 0,00\end{array}$ & $\begin{array}{c}0,09 \\
\pm 0,00\end{array}$ & $\begin{array}{c}0,09 \\
\pm 0,00\end{array}$ & $\begin{array}{l}0,08 \\
0,00\end{array}$ & $\begin{array}{c}6,88 \\
\pm 0,04\end{array}$ & $\begin{array}{c}2,04 \\
\pm 0,03\end{array}$ & $\begin{array}{c}1,78 \pm \\
0,02\end{array}$ & $\begin{array}{c}1,45 \\
\pm 0,01\end{array}$ & $\begin{array}{c}1,17 \\
\pm 0,06\end{array}$ \\
\hline Toxicity Reference Value (TRV) & \multicolumn{10}{|c|}{0,15} \\
\hline EI/TRV & 3,95 & 0,98 & 0,62 & 0,61 & 0,54 & 45,88 & 13,58 & 11,85 & 9,67 & 7,80 \\
\hline Estimated intake to MRL (AELMR $\left.{ }_{1}\right)$ & \multicolumn{5}{|c|}{0,35} & \multicolumn{5}{|c|}{0,70} \\
\hline
\end{tabular}




\section{International Journal of Science and Research (IJSR) \\ ISSN (Online): 2319-7064}

Index Copernicus Value (2013): 6.14 | Impact Factor (2015): 6.391

AELMR : estimated intake for a maximum residue level of aflatoxin B1 and total aflatoxins in cowpea; HO : Control with PICS bag (no biopesticide); H1: PICS bag with 0.7\% of biopesticide (w/w); H2: PICS bag with 2.5\% biopesticide (w / w), H3: PICS bag with 4.3\% of biopesticide ( $w / w)$, H4: PICS bag with $5.0 \%$ of biopesticide $(w / w)$

\section{Discussion}

The results in this study show that the post-harvest cowpea storage method in PICS bags with a biopesticide is able to reduce aflatoxin levels. Indeed, it has small amounts of aflatoxins B1, B2, G1 and G2 in PICS bags with biopesticide compared to controls without PICS bags or PICS bags without biopesticide that have high values at the end of storage. The reducing or inhibiting effect of PICS bag on aflatoxins is found that over a period of 4.5 months when values are low and substandard $(5 \mu \mathrm{g} / \mathrm{kg}$ for aflatoxin B1 and $10 \mu \mathrm{g} / \mathrm{kg}$ for AFT) [40]. These observed effects are due to the fact that the PICS bags are sealed with a vacuum that prevents the proliferation of insects and slowing the development of aflatoxins [41]. A 7 and 8 months, aflatoxin levels increase significantly and exceed the standards. As leaves of Lippa multiflora, insecticides and repellents effects proved since the amounts of aflatoxin in PICS bags containing leaves of Lippia multiflora remain weak and substandard [27], [42]. The inhibitory or fungicide effect of Lippa multiflora on Aspergillus flavus and Aspergillus parasiticus species responsible for the production of aflatoxins was highlighted by Goly et al, 2015 [43].

The water content of cowpea beans and the water activity (Aw) are positively correlated with the amounts of aflatoxin. (Tables 4 and 5). The water activity is an important parameter for food preservation. The most favorable conditions for a Apergillus flavus growth and aflatoxin production is a water activity (Aw) of 0.84 to 0.86 and a temperature between $25^{\circ} \mathrm{C}$ and $40^{\circ} \mathrm{C}$ [44], [45]. The water activity of cowpea controls bags without PICS and PICS without biopesticides would be the basis of increasing concentrations of aflatoxins in them. For PICS bags with $0.7 \%$ and $2.5 \%$ of biopesticide, the aflatoxin concentration is not excessive despite the value of the water activity is 0.86 to eighth months of storage. This is due to fungicidal and inhibitory effects leaves Lippia multiflora. The water activity is correlated to the water content of cowpea grains, increasing the water content also causes an increase in the aflatoxin concentration.

We note that the concentrations of aflatoxin B1 in PICS bags with biopesticide are below the standard which is $5 \mu \mathrm{g} / \mathrm{kg}$ according to Regulation [44] while the concentrations of total aflatoxins are well above the standard is $10 \mu \mathrm{g} / \mathrm{kg}$. These are the high concentrations of aflatoxin G1 which are the cause.

Compared to the toxicological reference value of $0.15 \mathrm{ng} / \mathrm{kg}$ bw / day [46]-[49], the estimated values exposure total aflatoxins and aflatoxin B1 cowpea are mostly higher except for $\mathrm{H} 2, \mathrm{H} 3$ and $\mathrm{H} 4$ aflatoxin $\mathrm{B} 1$ that have values below the reference. This finding may be a significant risk to the health of the Ivorian population if subjected to regular exposure to aflatoxins in diets based cowpea [50]

\section{Conclusion}

The evaluation of health parameters when storing cowpeas showed a continued increase in values of these parameters. Cowpea storage in polypropylene bags, causes a significant increase in humidity, the water activity and concentrations of aflatoxins B1, B2, G1 and G2 after 4.5 months of storage. For cons, the technique of triple bagging (PICS bags) showed its advantages in prolonging the storage of cowpea barely six months because at 7 months all parameters studied were beyond international standards prescribed for a good sanitary quality of cowpea. The use of Lippia multiflora leaves has potentially extended the sanitary quality of cowpea during the 8 months of storage. The inhibitory effects, fungicides, insecticides and repellents of Lippia multiflora leaves were found. Therefore, the leaves of Lippia multiflora could potentially be applied in food preservation, as an alternative to chemical pesticides to improve the protection of basic foods, particularly cereals and legumes. The technique is inexpensive, easy to perform and enter the Millennium guidelines of the recommended environment. However, due to the toxicity of aflatoxin, the study should be deepened in order to preserve the quality and ensure healthy nutrition cowpea after storage.

\section{References}

[1] Tengo NS, Technique de conservation des légumineuses et sécurisation de la production des paysans: cas du niébé dans le département du Diamare. Mémoire de Master, Institut Supérieur de Sahel, Université de Maroua, 142 p. 2011.

[2] Folefack et al, 2013. «Vulgarisation de la méthode du triple ensachage pour le stockage amélioré du niébé en zone sahélienne du Nord Cameroun: Enjeux et perceptions paysannes, » TROPICULTURA, XXXI (3), pp. 170-178, 2013.

[3] Mako François De Paul NeGBESSO, Goli Pierre ZOHOURI, Lassina FONDIO, Andé Hortense DJIDJI et Dramane KONATE «Etude des caractéristiques de croissance et de l'état sanitaire de six variétés améliorées de niébé [Vigna unguiculata(L.) Walp] en zone centre de Côte d'Tvoire » Int. J. Biol. Chem. Sci. VII (2), pp. $457-$ 467, 2013.

[4] I.Y. Dugje, L.O. Omoigui, F. Ekeleme, A.Y. Kamara, et H. Ajeigbe, ITTA Production du niébé en Afrique de l'Ouest: Guide du paysan, mai 2009.

[5] C. Agazounon; O. Coulibaly; V. Houndekon: Analyse des techniques de transformation de niébé en "'atta ${ }^{\text {eee }}$ au Bénin ; enquêtes socio-économiques, 2002

[6] Direction de l'eAlimentation et de la Nutrition Appliquée (DANA), Formation en technologies post-récoltes, Cotonou, Bénin, 1999.

[7] K.Hell, K. Cardwell, M. Setamou and H.-M. Poehling. The influence of storage practices on aflatoxin contamination in maize in four agroecological zones of 


\section{International Journal of Science and Research (IJSR) \\ ISSN (Online): 2319-7064}

Index Copernicus Value (2013): 6.14 | Impact Factor (2015): 6.391

Benin, West Africa. Journal of Stored Products Research, XXXVI, pp. 365-382, 2000.

[8] B. Dubale, A. Solomon, B. Geremew, R. Sethumadhava and S. Waktole. Mycoflora of grain maize (Zea mays L.) stored in traditional storage containers (Gombisa and sacks) in selected woredas of Jimma zone, Ethiopia. African Journal of Food, Agriculture, Nutrition and Development, XIV, pp. 8676-8694, 2014

[9] P. Fandohan, B. Gnonlonfin, K. Hell, W. F. Marasas and M. J. Wingfield. Impact of indigenous storage systems and insect infestation on the contamination of maize with fumonisins. African Journal of Biotechnology, V (7), pp 546-552, 2005.

[10] Amadi and D. Adeniyi. Mycotoxin production by fungi isolated from stored grains. African Journal of Biotechnology, VIII (7), pp. 1219-1221, 2009.

[11] M. Kankolongo, K.Hell and I.Nawa. Assessment for fungal, mycotoxin and insect spoilage in maize stored for human consumption in Zambia. Journal of Sciences Food and Agriculture, 10 p, 2009

[12] Udoh J, Cardwell K, Ikotun T. Storage structures and aflatoxin content of maize in five agroecological zones of Nigeria. Journal of Stored Products Research, 36, pp. 187-201, 2000.

[13] Kouadio J. H. Ochratoxine A en côte deivoire moisissures ochratoxinogènes, exposition humaine et détoxification des aliments. Rev. Ivoir. Sci. Technol., XX, pp. 87-103, 2012.

[14] CD. Kurtzman, BW. Horn, CW. Hesseltine, "Aspergillus nomius, a new aflatoxin producing species related to Aspergillus flavus and Aspergillus tamari”, Antonie van Leeuwenhoek, LIII, pp. 174-158, 1987.

[15]M. McLean, M. Dutton, "Cellular interactions and metabolism of aflatoxin: and update", Pharmacol Ther, LXV, pp. 163-193, 1995.

[16] GD. Kirk, E. Bah, R. Montesano, "Molecular epidemiology of human liver cancer: insights into etiology, pathogenesis and prevention from the Gambia”,Carcinogenesis, XXVII, pp. 2070-2082, 2006.

[17] CP. Wild, Y. Gong, "Mycotoxins and human disease: A largely ignored global health issue",Carcinogenesis 31 (1): 71-82, 2010.

[18] Y. Liu, F. Wu, "Global Burden of Aflatoxin-induced hepatocellular carcinoma: A Risk Assessment", Environ Health Perspect CXVIII (6), pp. 818-824, 2010.

[19] J. Keenan, P. Jolly, P. Preko, J. Baidoo, J. Wang, TD. Phillips, JH. Williams, G. McGwin, "Association Between Aflatoxin B1 Albumin Adduct levels and tuberculosis infection Among HIV+ Ghanaians", iMedPub Journals, II (10), 3823p, p.230, 2011.

[20]AFSSA (Agence Française de Sécurité Sanitaire des Aliments), "Evaluation des risques liés à la présence de mycotoxines dans les chaînes alimentaires humaine et animale. Rapport synthétique", p 82, décembre 2006.

[21] JL. Richard, "Mycotoxins, Toxicity and Metabolism in Animals- A system Approach Overview. Mycotoxins and Phycotoxins-Developpements in Chemistry", Toxicology and Food Safety, Ed by M. Miraglia H., van Egmond C., Brera and J. Gilbert. USA, pp. 363- 397, 1998.

[22] YY. Gong, V. Egal, A. Hounsa, PC. Turner, AJ. Hall, V. Cardwell, CP. Wild, "Determinants of aflatoxin exposure in young children from Benin and Togo, West Africa: the critical role of weaning",Int. J. Epidemiol. XXXII, pp. 556-562, 2003.

[23] YY. Gong, A. Hounsa, El. Sharif, PC. Turner, AE. Sutcliffe, AJ. Hall, K. Cardwell, CP.Wild, "Post weaning exposure to aflatoxin results in impaired child growth: A longitudinal study in Benin, West Africa", Environ. Health Perspect, pp. 112-113, 2004.

[24] Codex Alimentarius, "Programme mixte FAO/WHO sur les normes alimentaires ; Comite du Codex sur les contaminants dans les aliments. Avant-projet de niveaux maximaux pour les aflatoxines totales dans les figues sèches (N11-2010)",La Haye, Pays-Bas,CX/CF 11/5/7, $27 \mathrm{p}$, Décembre 2010.

[25] ProMED, "Aflatoxicosis, Human-Kenya", 2004 [Online] Available: www.promed.isid.harvard.edu. [Accessed: May 09, 2006].

[26] Damien Dagbedji Toffa «Étude de la contamination de certains aliments d'origine végétale de la République du Niger les moisissures toxinogènes » Thèse de doctorat en mycologie-environnement, Université Mohammed V, faculté des sciences rabat, Juin 2015.

[27] T. Ngamo, M. Ngassoum and F. Malaisse. Use of essential oil of aromatic plants as protectant of grains during storage, Agricultural Journal, II, pp. 204-209, 2007.

[28]M. Isman. Botanical insecticides, deterrents, and repellents in modem agriculture and an increasingly regulated world. Annual Review of Entomology, LI, pp. 45-66, 2006

[29] L. Alpsoy. Inhibitory effect of essential oil on aflatoxin activities. African Journal of Biotechnology, IX, pp. 2474-2481, 2010

[30] N. Tatsadjieu, J. Dongmo, M. Ngassoum, F.-X Etoa. and C. Mbofung. Investigations on the essential oil of Lippia rugosa from Cameroon for its potential use as antifungal agent against Aspergillus flavus Link ex. Fries. Food Control, XX, pp. 161-166, 2009

[31]V. Tia. Pouvoir insecticide des huiles essentielles de cinq espèces végétales aromatiques de côte deivoire dans la lutte contre les insectes phytophages bemisia tabaci Gen. et plutella xylostella Lin. : Composition chimique et tests deefficacité. Thèse de doctorat en biochimie sciences des aliments, Université Félix HouphouëtBoigny Abidjan, 205 p. 2012.

[32] Ekissi A. C., Konan A. G., Yao-Kouame A., Bonfoh B. et Kati-Coulibaly S. "Sensory evaluation of green tea from Lippia multiflora Moldenke leaves," European Scientific Journal, X, pp. 534-543, 2014.

[33] AOAC, Official Methods of Analysis of the Association of Analytical Chemists. $17^{\text {th }}$ Edition. Washington, DC, USA, 2000

[34] Mc Cormick, Determination of water activity. McCormick and Company, Inc. Manual of technical methods and procedures, Baltimore, USA, 1995.

[35]AOAC, "Aflatoxins in corn, raw peanuts and peanut butter: immunoaffinity column (aflatest) method," AOAC, 2005

[36] International R. Kroes, D. Muller, J. Lambe, P. Verger, A. Visconti, "Assessment of intake from the diet" Food and Chemical Toxicology, XL, p. 327-385, 2002.

\section{Volume 5 Issue 7, July 2016 www.ijsr.net}




\section{International Journal of Science and Research (IJSR) \\ ISSN (Online): 2319-7064 \\ Index Copernicus Value (2013): 6.14 | Impact Factor (2015): 6.391}

[37] OMS (Organisation Mondiale de la Santé), "Régime alimentaire, nutrition et prévention des maladies chroniques", Rapport d'une consultation OMS/FAO deexperts, Genève, OMS, Série de rapport technique, $\mathrm{n}^{\circ}$ 916, p189, 2003.

[38] A. S. Langyintuoa, B.J. Lowenberg-DeBoer, M. Faye, D. Lambert, G. Ibro, B. Moussa et al, "Cowpea supply and demand in West and Central Africa" Field Crops Research LXXXII, pp. 215-231, 2003

[39] COMMISSION REGULATION (EU) of 29 April 2011 amending Regulation (EC) No 1881/2006 setting maximum levels for certain contaminants in foodstuffs, $\mathrm{N}^{\mathrm{o}} 420,2011$

[40] Règlement (CE) $\mathrm{N}^{\circ}$ 1881/2006 de la commission du 19 décembre 2006 portant fixation de teneurs maximales pour certains contaminants dans les denrées alimentaires (Texte présentant de l'intérêt pour l'EEE) JO L 364, p. 5, du 20.12.2006,

[41] Baoua I.B., L. Amadou, B. Ousmane, D. Baributsa, L.L. Murdock : "PICS bags for post-harvest storage of maize grain in West Africa" Journal of Stored Products Research LXIII, pp. 20-28, 2014

[42] L. Niamketchi, H. G. Biego, O. Chatigre, D. Amané, E. Koffi, A. Adima. Optimization of Post-Harvest Maize Storage using Biopesticides in Granaries in Rural Environment of Côte d'Tvoire, International Journal of Science and Research, IV (9), pp. 1727-1736, 2015.

[43] Cyrille GOLY, Yaya SORO, Brice KASSI, Adjehi DADIÉ, Siaka SORO and Marcellin DJE. Antifungal activities of the essential oil extracted from the tea of savanna (Lippia multiflora) in Côte d'Tvoire Int. J. Biol. Chem. Sci. IX (1), pp. 24-34, February 2015

[44]Agence Française de Sécurité Sanitaire des Aliments, «Evaluation des risques liés à la présence de mycotoxines dans les chaînes alimentaires humaine et animale ». Coordination rédactionnelle Jean Marc Fremy ; Coordination éditoriale Carole Thomann, Mars 2009

[45] Commission Européenne, Règlement (CE) No401/2006 de la commission du 23 février 2006 portant fixation des modes de prélèvement d'échantillons et des méthodes d'analyse pour le contrôle officiel des teneurs en mycotoxines des denrées alimentaires. Journal Officiel de l'Union Européenne L70/12, 2006.

[46] SCF (Scientific Committee for Food), "European Commission DG XXIV Unit B3. Thirty-fifth report. Opinion on Aflatoxins B1, B2, G1 et G2 and M1", Expressed on 23 September, 1994.

[47]CSHPF (Conseil Supérieur d'Hygiène Publique de France), "Les mycotoxines dans l'alimentation : évaluation et gestion du risque", éds TEC \& DOC, 1999.

[48] JECFA (Joint FAO/WHO Expert Committee on Food Additives and Contaminants), "Evaluation of certain food additives and contaminants", Fourty-nine report, WHO Technical Report Series $\mathrm{N}^{\circ}$. 884, pp. 69-77, Geneva, 1999.

[49] JECFA, (Joint FAO/WHO Expert Committee on Food Additives and Contaminants), "Safety evaluation of certain mycotoxins in food",WHO Food Additif Series; 47, 2001.

[50] NIAMKETCHI Léonce, BIEGO Godi Henri, SIDIBE Daouda, COULIBALY Adama, KONAN Neeguessan
Ysidor, CHATIGRE Olivier: "Changes in Aflatoxins Contents of the Maize (Zea Mays L.) Stored in Clay Granaries with use of Biopesticides from Rural Conditions and Estimation of their Intake", International Journal of Environmental \& Agriculture Research, II (5), 2016.

\section{Author Profile}

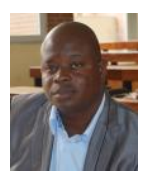

KONAN Kouakou Constant was born in December 22, 1974. He got his Master in Food Nutrition from Félix HOUPHOUËTBOIGNY University of Abidjan, Côte d"Ivoire in 2012-2013. Since academic year 2013-2014, he is PhD student in the Training and Research Unit of Biosciences, Biotechnology and Food Science option

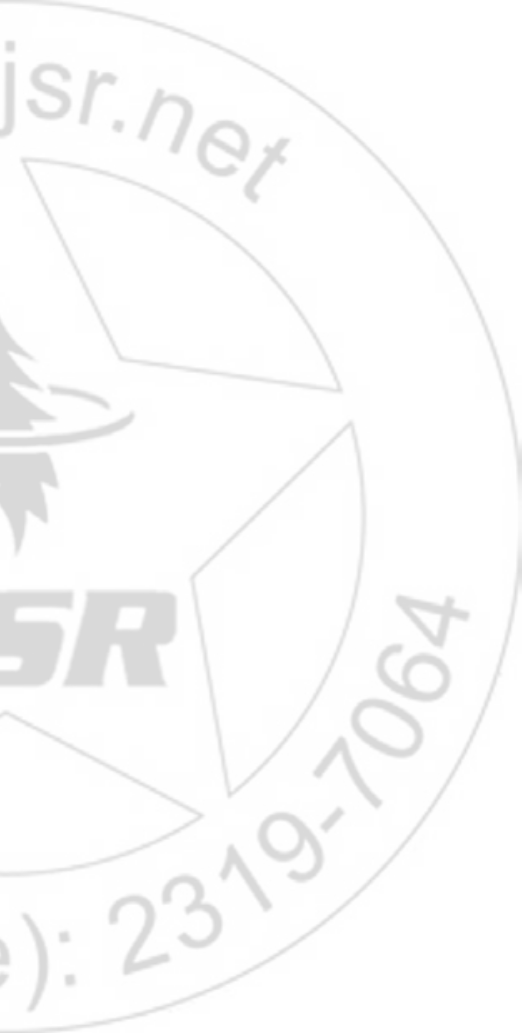

\section{Volume 5 Issue 7, July 2016}

www.ijsr.net 